This item was submitted to Loughborough's Research Repository by the author.

Items in Figshare are protected by copyright, with all rights reserved, unless otherwise indicated.

\title{
Factors controlling the temporal variability in dissolved oxygen regime of salmon spawning gravels
}

PLEASE CITE THE PUBLISHED VERSION

http://dx.doi.org/10.1002/hyp.9565

PUBLISHER

(c) John Wiley \& Sons, Ltd.

VERSION

AM (Accepted Manuscript)

LICENCE

CC BY-NC-ND 4.0

\section{REPOSITORY RECORD}

Sear, D.A., Ian Pattison, A.L. Collins, M.D. Newson, J. Iwan Jones, P.S. Naden, and P.A. Carling. 2019. "Factors Controlling the Temporal Variability in Dissolved Oxygen Regime of Salmon Spawning Gravels". figshare. https://hdl.handle.net/2134/13480. 
This item was submitted to Loughborough's Institutional Repository (https://dspace.lboro.ac.uk/) by the author and is made available under the following Creative Commons Licence conditions.

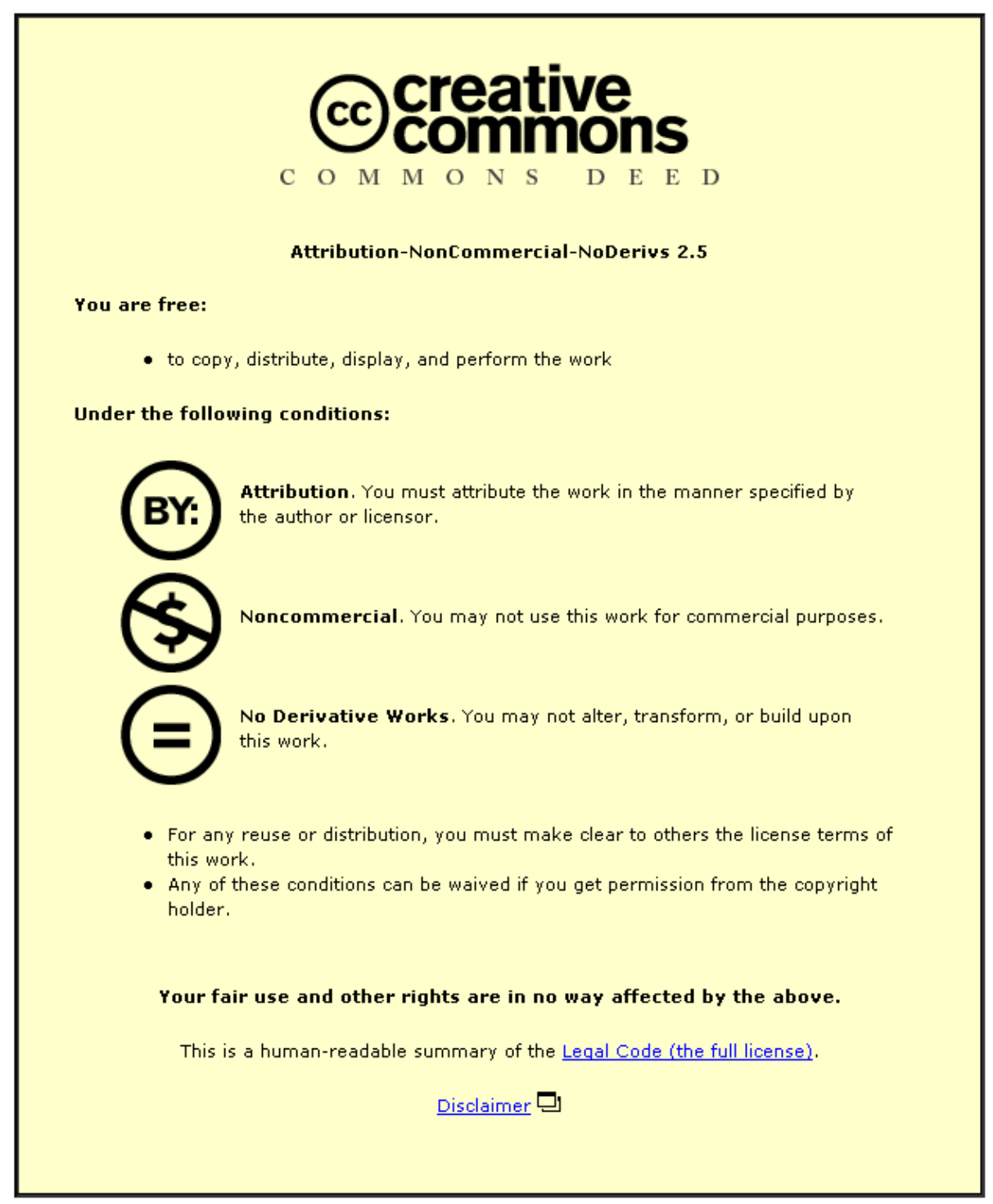

For the full text of this licence, please go to: http://creativecommons.org/licenses/by-nc-nd/2.5/ 


\section{Factors controlling the temporal variability in dissolved oxygen regime of salmon spawning gravels}

Sear, D.A.1*, Pattison, I.1, Collins, A.L.2, Newson, M.D.3, Jones, J.I.4, \& Naden, P.S.5, Carling. P.A. 1

${ }^{1}$ Department of Geography, University of Southampton, Highfield, Southampton S017 1BJ, UK

.d.sear@soton.ac.uk

${ }^{2}$ Soils, Agriculture and Water, ADAS, Woodthorne, Wergs Road, Wolverhampton WV6 8TQ, West

Midlands,UK. Adrian.collins@adas.co.uk

${ }^{3}$ Tyne Rivers Trust, Horesley, Northumberland, NE15 OPA, UK. Malcolm.newson@tyneriverstrust.org

${ }^{4}$ School of Biological and Chemical Sciences, Queen Mary University of London, Mile End Road,

LondonE1 4NS, UK. I.J.jones@qmul.ac.uk

${ }^{5}$ Centre for Ecology and Hydrology, Crowmarsh Gifford, Wallingford, Oxon, UK., psn@ceh.ac.uk

* Corresponding Author

\section{Introduction}

There has been a long term interest in understanding the incubation environment within salmonid spawning gravels. This focus has been motivated primarily by concerns over the impact of increased fine sediment loadings released from a range of catchment sources including, amongst others, forestry or agricultural activity (Ringer \& Hall 1987; Collins et al., 2011). Greig et al.,(2005a;2007a) and Sear et al., (2008a) have shown how the accumulation of fine sediment $(<1 \mathrm{~mm})$ influences the supply of oxygen to incubating salmonid eggs via three main processes; 1 ) physical occlusion of the micropores on the surface of the egg resulting in reduced oxygen diffusion through the egg wall (Greig et al., 2005b); 2) physical occlusion of the pore spaces between gravel particles in the bed, resulting in reduced interstitial flow velocity and longer flow paths and 3) increased oxygen demand arising from active elements within the infiltrated sediments resulting in a reduction in oxygen concentration; termed Sediment Oxygen Demand (SOD). Greig et al., (2005a) highlighted that it is a combination of these factors which can result in egg mortality due to fine sediment accumulation, noting that the dominance of any specific factor can vary within a spawning bed, between different spawning beds in the same river, between river catchments. Given the timing of the application of different materials to agricultural land during the farming year, seasonality will also be important.

Attention has also focussed on the role of upwelling groundwater on salmonid incubation (Hansen 1975) with low dissolved oxygen concentration as a control on the quality and productivity of salmon spawning habitat (Geist 2000; Malcolm et al., 2008, 2009; Soulsby et al., 2009). Typically, water within the hyporheic zone; (defined in this paper as that portion of the fluvial sediments in which there is exchange of water from the stream and shallow groundwater sources into the riverbed 
sediments within timescales of days to months), is composed of upwelling groundwater and advected surface water. The influx of water from these sources is controlled by dynamic processes operating over a variety of spatial and temporal scales (Lawler et al., 2010). In complex landscapes, hyporheic exchanges are typically composed of localised hyporheic processes embedded within larger hillslopegroundwater systems (Malard \& Hervant, 1999). At smaller scales, the riverbed can be viewed as a mosaic of spatially distinct surface-subsurface exchange patches in which the timing and magnitude of exchange is temporally variable (Malard \& Hervant 1999). Critical to salmonids is the quality of groundwater and its access to the egg zone (typically $0.1-0.3 \mathrm{~m}$ below the stream bed depending on species and fish size; Crisp \& Carling 1989). The quality of upwelling groundwater is spatially and temporally variable, but in general, within areas in which flow paths and residence times are long (years-centuries) and where upwelling flow paths pass through organic rich sediments, corresponding dissolved oxygen concentrations can be very low (<2mg/l);(Malcolm et al., 2006).

Temperature is one of the most important variables affecting the saturation constants of dissolved gasses including oxygen, and the metabolic rates of salmonid embryos (Hauer \& Hill 2006; Chevalier et al 1984). Dissolved oxygen varies non-linearly with temperature, such that increasing temperature reduces the solubility and hence availability of DO. The thermal regime of water within the redd is influenced by the relative contributions from groundwater and surface water sources; the latter source is influenced by air temperatures during the incubation period (Acornley 1999; Hannah et al., 2009).

Thus, the factors controlling the quality of the incubation environment include those associated with the quality, character and quantity of sediment (both framework and matrix/interstitial), those which control the flux and quality of water within the egg zone, and those that control the thermal regime. To date, the emphasis of research has tended to be on one factor in isolation. Furthermore, studies linking salmonid spawning quality to groundwater have tended to be in smaller headwater streams (Malcolm et al., 2003; Soulsby et al., 2009), as opposed to the larger scales where the interactions between, and relative dominance of, sediment versus water sources and thermal regime, are potentially more difficult to disentangle and interpret.

In this paper we detail an experiment undertaken within a Strahler fifth-order floodplain river. The objectives of the experiment were to (i) quantify the DO regime within the egg zone; (ii) quantify the factors controlling the DO regime including vertical hydraulic gradient, fine sediment accumulation, bed mobility and thermal regime, and; (iii) undertake numerical modelling to quantify the relative contributions of sediment accumulation, thermal regime and other factors, including groundwater upwelling, on the DO regime within the egg pocket, and; (iv) to discuss the implications of the above for embryo survival.

\section{Field Site}

The River Rede is a fifth-order tributary of the North Tyne rising in the Cheviot Hills in the North East of England. This $215 \mathrm{~km}^{2}$ upland catchment lies on moderately permeable Carboniferous sandstone and limestone formations that are mostly covered by drift deposits of glacial boulder clay and upland peat. The permeability of the dominant base rocks results in a baseflow index of 0.32 , whilst the impermeable drift 
deposits of boulder clay and rocks in the headwaters, create a runoff-dominated flow regime characterised by high rates of rise and recession. Catcleugh Reservoir (direct supply to a pipeline) has, since 1905, affected the headwater flow and sediment inputs to the River Rede, however, Petts et al., (1993) demonstrated that it had a very restricted influence on invertebrates and that while 'siltation had occurred, it was patchy down the main river'. Table 1 and Figure 1 present a summary of the physical characteristics of the field site.

Land cover in the catchment is dominated by improved grassland (pasture) in the valley and upland moorland underlain by peats. A substantial area (22\%) is coniferous plantation forest. The main river and its tributaries upstream of the study site are all assigned Good Ecological Status (GES) under the Water Framework Directive (WFD) classification of water bodies. However, three tributaries upstream of the study site have been the subject of investigation and ameliorative measures for silt reduction by the local Environment Agency and Tyne Rivers Trust.

The headwaters of the River Rede are inaccessible to migratory fish as a result of the construction of Catcleugh reservoir. However, for most of the main river length and tributaries including the field site, the river supports a migratory salmon and sea trout population. Angling data are few, however, electro-fishing surveys and an annual broodstock collection of adult salmon and sea trout for the Kielder Hatchery suggest a vigorous local salmonid stock (Environment Agency, 2008). The study site was identified by local Environment Agency and Rivers Trust fisheries staff based on previous observations of salmon spawning. The site is typical of the available habitat in the middle reaches of the river Rede, which tends to be characterised by short riffles and runs, separated by longer pools.

The channel in the vicinity of the study site was channelized in the 1930's and again in the 1950's to aid land drainage for agricultural improvement (Brookes, 1988). The resulting channel morphology is best described as an embanked, incised channel with a gravel bed. The uncut bulk gravels (i.e. surface and subsurface sediments) have a median $\left(D_{50}\right)$ of $29.7 \mathrm{~mm}$ and contain $10.5 \%$ by dry weight of fines $<1 \mathrm{~mm}$, of which $11.4 \%$ is sand and $1 \%$ is silt and clay. This size distribution is similar to the observations of Petts et al., (1993) who reported that the levels of sediment finer than $1 \mathrm{~mm}$ were typically less than $10 \%$ (based on freeze-coring bulk uncut riffle sediments). The channel at the experimental field site is a pool-riffle-run-pool sequence, with a lateral gravel bar on the true right bank (Figure 1). Banks are up to $3 \mathrm{~m}$ high and are composed of alluvial sands with fine layers of silt and clay overlying basal (fluvial) gravels. The left bank is protected by a range of wooden piling and gabion revetments, the right bank is eroding upstream of the redds through cattle poaching. The bank vegetation is heavily grazed and dominated by grasses, as is typical for upland floodplain streams in the UK. The Tyne Rivers Trust has initiated a programme of silt reduction procedures focussing on fencing banks within the river network. In common with UK floodplain rivers, the floodplain at the field site is underlain by a network of palaeochannels containing fine silts and clays with high organic content (Hildon, 2005). As a result of interest in the impacts of river regulation and in the sediment yield and habitat quality of the River Rede system (notably for silt-sensitive Freshwater Pearl Mussels: Margaritifera margaritifera) numerous supplementary studies set the context for the study site (Petts et al., 1993; Milan et al., 2001; Knox, 2008; Clapham 2011; Perkins, 2011). 
The impact of flow regulation on the field observations is considered to be minimal. The field site is influenced by the Catcleugh reservoir which impounds $40 \mathrm{~km}^{2}$ (18.6\%) of upstream catchment area. The influence on flows is a maximum abstraction of $63.7 \mathrm{ML} /$ day, dropping to $3.5 \mathrm{ML} /$ day during drought conditions (Environment Agency, 2008). The precise influence on flow regime is difficult to establish because the gauging record at the field site is short ( $<10$ years). However, during high flows when the reservoir is full (normal winter conditions) excess flow is controlled by a spillway. The impacts on the flood hydrograph are to reduce its peak. During low flows, the compensation flow of 3.5ML/day maintains a minimum discharge. More research outside the scope of this project would be required to model the impacts on the hydrological regime, but it is assumed that the saturated state of the catchment over the field season and the high reservoir levels limited any impact of regulation to minor reductions in flood peak relative to natural.

\section{Methods}

The field site was established on $17^{\text {th }-} 18^{\text {th }}$ February 2011, which represents the very latest spawning period for Atlantic Salmon in this river system (Environment Agency, 2008; Richard Bond pers comm.). Earlier access to the field site during the main spawning period was hampered by heavy snow throughout December 2010 through to early February 2011. Three artificial salmon redds were dug in the head of the riffle where redds had been observed. Flows over the redd sites prior to cutting were $0.22 \mathrm{~m}$ deep. The method of artificial redd cutting followed the method outlined by Greig et al., (2005a; 2007a). A single mesh sediment basket was installed in each redd containing a standpipe to allow access to the egg zone (Figure 1c). Dissolved oxygen, temperature (YSI Pro5000) and intragravel flow velocity (conductiometric standpipe; see Grieg et al., 2005c) were sampled in each standpipe at the start (freshly cut) and end of the experiment. At the end of the field experiment, the sediment basket was removed from each redd using a nylon bag which retained all fine sediment which had ingressed the basket sampler during the period of deployment. In one artificial redd (Redd 1), DO and temperature were measured using an Aandera 4175 Optode, (DO accuracy $+/-5 \%$, temperature accuracy $+/-0.5 \%$ ) located at $0.2 \mathrm{~m}$ depth below the redd surface which represents the modal spawning depth of Atlantic salmon in UK upland rivers (Crisp \& Carling, 1989). The DO content of the river water at a height of $0.1 \mathrm{~m}$ above the redd surface was sampled using another Aandera 4175 Optode. Both probes were cross-calibrated prior to installation and again after removal to check for accuracy and repeatability, which in both cases was within the error of the instruments $\left(1 \% \mathrm{DO}, 0.1^{\circ} \mathrm{C}\right)$.

Intragravel flow velocity (IGV) at the experimental site was measured using a conductiometric standpipe technique as outlined in Grieg et al., (2005c). The sampling volume was $63 \mathrm{~cm}^{3}(5 \mathrm{~cm}$ vertical sampling range) and this represented bulk flow rate through the egg zone over a depth between $0.2-0.25 \mathrm{~cm}$ below the gravel surface (Greig et al., 2007a). Discharge was measured at an Environment Agency gauge located $30 \mathrm{~m}$ upstream of the site (Figure 1b).

The sediment transport regime at the field site was quantified using a combination of pump sampling and turbidity probes and a novel bedload impact sensor. Suspended sediment was measured using a combination of daily water sampling $(0.5 \mathrm{~L}$ sampled at 23:00) using a ISCO automated pump sampler set at $0.05 \mathrm{~m}$ above the local bed level at the sampler and an Analite 9000 turbidity probe (accuracy +/- 1\%). We measured 
suspended sediment at this level to capture the near-bed concentration which the SIDO-UK model (Alonso et al 1988), laboratory (Carling 1984) and field observations (Grieg et al., 2005a) demonstrate is strongly related to accumulation in the framework gravel. In the event, the turbidity probe failed. Suspended solid concentrations were, therefore, estimated from a rating curve derived between measured suspended sediment concentration from the pump sampler (y) in mg/l and discharge $(\mathrm{x})$ measured from the gauging station (Figure 2a). Ideally, such rating curves should have as many data points as possible, but in the event the sampler was knocked over by the highest magnitude floods and all samples lost. The resulting relationship was stable across both the rising and falling limb of storm hydrographs (y $\left.=47.762 x-99.251 ; \mathrm{r}^{2}=0.8382, \mathrm{p}<0.001 ; \mathrm{n}=53\right)$. To quantify the grainsize of the suspended sediment, a bulk sample of suspended sediment was collected over the incubation period using an isokinetic sampler (Phillips et al., 2000), set at $0.05 \mathrm{~m}$ above the bed level, $2 \mathrm{~m}$ upstream of the redds. The bulk sample was wet sieved down to $63 \mu \mathrm{m}$, and the resulting sub-sample $<63 \mu \mathrm{m}$ disaggregated chemically, and analysed for particle size using a Malvern Mastersizer 2000. These data were subsequently used in parameterizing the SIDO-UK model (see below).

Bed mobility can be detrimental if scour depth is equal to, or greater than, egg burial depth (DeVries, 2008), but Sear et al. (2008b) demonstrated that limited scour may remove accumulated fine sediment and increase the connectivity between stream water and the hyporheic zone. To quantify periods when the redd sediment was mobile, we installed a bedload impact sensor level within the stream bed, $1 \mathrm{~m}$ immediately downstream of the redds. This position was selected to maximise the probability of measuring mobility of redd sediments, though it is possible that some impacts are from material over-passing the redds. However, since the effect of redd cutting results in an overloose bed, the latter is assumed to be unlikely, and we interpret the impacts as evidence of redd sediment mobility. The sensor records the number of impacts and logs the total every 10 minutes, with intensity related to increasing bed mobility (Richardson et al., 2004). Scour depths around the redd were recorded by measuring the exposure of the mesh baskets. In the event, these remained flush with the river bed surface indicating no net scour over the redds during the incubation season, though clearly we cannot account for episodes of scour or fill during phases of bed mobility. All probes used in the field experiment were crosscalibrated for time/date and set to sample every minute and the average logged every 10 minutes. Unfortunately, no measurement of IGV was possible during the incubation period due to malfunction of the conductiometric probe. Values were taken at the start and end of the field campaign.

Vertical hydraulic gradient (head) was measured using two piezometers installed $1 \mathrm{~m}$ upstream of the redds. A Schlumberger DI501 Mini-Diver@) (range 10m, accuracy $0.2 \%$ FS) was installed $0.25 \mathrm{~m}$ below the gravel bed at the same elevation as the DO probe and standpipe within the redds. A Druck PDCR/1840 pressure transducer (range $7 \mathrm{~m}$, accuracy $0.06 \%$ ) was installed in the second piezometer, level with the gravel bed. The data logger failed after the first event and as a result a continuous record of head over the whole incubation period was unavailable. However, a short record at the start of the period was collected and is reported in this paper.

Unfortunately, owing to the delayed late start of the experiment, there were no Atlantic salmon or Sea trout eggs available from local hatcheries and so survival to 
hatch data are unavailable for this site. Instead, we used a temperature based hatch prediction model (Crisp 1991) to predict the date of $50 \%$ hatching using the temperature records from within the artificial redd; this procedure yielded a predicted median hatch time of 22/04/2011. Data are presented for this period.

\section{The SIDO-UK model}

To differentiate between the DO regime resulting from the accumulation of sediment (represented by blocking of gravel interstices by fine sediment and hence oxygen supply rate, and the oxygen consumption of this accumulated sediment) and that due to other factors (e.g. groundwater upwelling), the field data were used to calibrate a physically-based sediment intrusion and dissolved oxygen model (SIDO-UK; Carling et al., 2003; Sear, 2010, Pattison et al., in review). SIDO-UK is a modified version of the USDA SIDO model (Alonso et al., 1996). Full details of the SIDO model are easily accessed online and are presented elsewhere (e.g. Havis et al., 1993; Alonso et al., 1998;1996; Carling et al., 2003; USDA, 2011). As such, we do not reiterate the detail here. Instead we represent the main equations and briefly describe the model and its parameterization and calibration. In SIDO/SIDO-UK, hyporheic exchange is assumed to occur only at the scale of the redd. There is no explicit representation of groundwater contribution. Oxygen supply to incubating salmonid embryos is assumed to be a function of the concentration in the stream water (temperature dependant), the inter-gravel flow rate and the consumption of dissolved oxygen in the redd. The latter is represented in the model by the Sediment Oxygen Demand (SOD) of the material accumulated in the void spaces within the redd, and the time-dependant egg oxygen consumption (Alonso et al., 1996). We hypothesized that by calibrating the SIDO-UK model using measured sediment accumulation, we could isolate the effects on DO regime resulting from flow rate, fine sediment accumulation and temperature. Therefore, we would be able to identify the significance of other factors (e.g. groundwater upwelling, additional respiration from organisms within the redd, geochemical processes). We recognise that identification of these specific processes must remain uncertain in the absence of a complete time series of VHG and hydrochemical/isotopic indicators of source water.

SIDO / SIDO-UK is a deterministic model which operates on two coupled domains (stream and redd). Therefore, the model can be considered as being composed of two sub-models representing the processes occurring in these two areas. First, the flow of oxygen-saturated and sediment-laden water over a gravel stream bed is simulated in the stream domain. Output from the stream-domain simulation is then passed on to the redd domain. Fine sediment and dissolved oxygen are transported across the streamsubstrate interface according to hydraulic-pressure differences, sediment particle size, substrate pore size, and water temperature. The SIDO-UK model is designed to handle any mixture of fine sediment matrix and gravel framework. An important limitation of the model is that it does not simulate the contribution to fine sediment accumulation from bed load. Rather, it assumes that all fine $(<1 \mathrm{~mm})$ sediment accumulates from deposition of suspended sediment at the water/bed interface.

SIDO-UK represents the redd domain as a fixed grid structure. Intra-gravel flow, calculated on a daily timestep, is represented by Darcy's law, which states that the discharge $(q)$ is given by: 


$$
\vec{q}=-K \nabla h=\left(-K \frac{\partial h}{\partial x},-K \frac{\partial h}{\partial y}\right)
$$

where $K$ is the hydraulic conductivity, $\nabla \mathrm{h}$ is the hydraulic gradient, $\partial \mathrm{h}$ is the change in head in the downstream (x) and vertical (y) dimensions; $h$ is calculated by the 1-D HECRAS model used in SIDO-UK to simulate the hydraulics over the spawning riffle and redd domain (Alonso et al., 1988; 1996). Values for hydraulic conductivity $(K)$ and porosity $(\varepsilon)$ are calculated for each cell $(\mathrm{j}, \mathrm{k})$ at time $\mathrm{t}^{\mathrm{n}}$ within the redd domain using the grainsize and mass of fine sediment predicted to have accumulated within the cell over a day (Alonso et al., 1996) according to:

$$
\begin{gathered}
\varepsilon_{\mathrm{jk}}^{\mathrm{n}}=1-\frac{\gamma_{\mathrm{g}}}{2.65 \gamma_{\mathrm{w}}\left(1-\mathrm{P}_{\mathrm{f}, \mathrm{jk}}^{\mathrm{n}}\right)} \\
\mathrm{K}_{\mathrm{jk}}^{\mathrm{n}}=\mathrm{af}\left(\varepsilon_{\mathrm{jk}}^{\mathrm{n}}\right)\left(\mathrm{d}_{\mathrm{e}, \mathrm{jk}}^{\mathrm{n}}\right)^{2}
\end{gathered}
$$

where: $\mathrm{a}=0.0105$, an empirical calibration coefficient calculated from field data used to parameterize the original SIDO model and left unchanged in SIDO-UK, $f(\varepsilon)=$ porosity function, $\mathrm{d}_{\mathrm{e}}=$ effective particle diameter of the composite substrate material $(\mathrm{mm}), \gamma_{\mathrm{g}}$ and $\gamma_{\mathrm{w}}$ are the density of sediment and water respectively. The expressions for $\mathrm{f}(\varepsilon)$ and $\mathrm{d}_{\mathrm{e}}$ are:

$$
\begin{gathered}
f(\varepsilon)=\frac{\varepsilon^{3}}{(1-\varepsilon)^{2}} \\
d_{e}=\left[\frac{1-P_{f}}{d_{g}}+\frac{P_{f} P_{s}}{d_{s}}+\frac{P_{f}\left(1-P_{s}\right)}{d_{c}}\right]^{-1}
\end{gathered}
$$

where $d_{g}, d_{s}$, and $d_{c}$ are effective diameters of gravel, sand, and clay-silt materials, and $\mathrm{P}_{\mathrm{s}}$ is the ratio of sand matrix to total mass of matrix, and $\mathrm{P}_{\mathrm{f}}$ is the ratio of intruded matrix to total substrate mixture.

The rate of fines infiltrating into the redd is assumed to be directly related to the near bed concentration of suspended sediment according to;

$$
\frac{\bar{C}}{C_{z}}=\frac{u_{*}}{V}\left(\frac{\zeta_{z}}{1-\zeta_{z}}\right)^{\beta} F\left(\zeta_{z}\right)
$$


where

$$
F\left(\zeta_{z}\right)=\int_{\zeta_{a}}^{1}\left[z_{0}-z_{1}(1-\zeta)^{2}\right]\left(\frac{1-\zeta}{\zeta}\right)^{\beta \sigma} * \exp [-2 \beta(1-\sigma)(2 \zeta-1)] d \zeta
$$

where $z_{0}=k^{-1} \ln \left(d / D_{50}\right)+1.44\left(d / D_{50}\right)^{0.562}, z_{1}=(2 \alpha)^{-1}$ and $\bar{C}$ is the average sediment concentration, $C_{z}$ is the sediment concentration at depth $z, u *$ is the bed friction velocity, $V$ is the average flow velocity, $k$ is the Von Karman constant $=0.41, \alpha$ is 0.046, $\beta=w_{s} d / 4 \varepsilon_{\max }$ where $w_{s}$ is the settling velocity, $d$ is the depth, $D_{50}$ is the sediment size, and $\varepsilon_{\max }$ is the maximum sediment diffusion coefficient. In this study

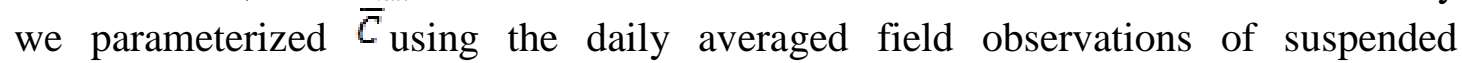
sediment at $0.05 \mathrm{~m}$ above the bed. The rationale for using this value rather than an average value is that it will include saltating bed material which is not explicitly modelled in SIDO-UK. The Einstein-Brown (Brown, 1950) formula is used to represent bedload transport, but this is used to infill the pot zone of the redd and to predict when the redd becomes scoured. Thus the model is limited to scenarios where the bed is stable and the majority of fine sediment is derived from suspended sediment. This situation has been shown to be the case in most studies in UK salmon spawning streams (Greig et al., 2008, Greig et al 2005a; Sear \& Acornley 1999) and laboratory studies (Carling 1984).

Intra-gravel sediment and oxygen transport, calculated on a sub-daily timestep to minimise numerical dispersion, is represented by two processes; advection and dispersion (Alonso et al., 1996). Assuming incompressible flow, these processes can be represented by the following equation:

$$
\frac{\partial c}{\partial t}+u \frac{\partial c}{\partial x}+v \frac{\partial c}{\partial y}=f
$$

where $\mathrm{u}$ and $\mathrm{v}$ are the advective velocity components in the $\mathrm{x}$ (downstream) and $\mathrm{y}$ (vertical) flow directions respectively, $c$ is the concentration of sediment or oxygen. For modelling dissolved oxygen, $f$ represents the combined rate of consumption of dissolved oxygen by organic matter and salmonid eggs or fry. When equation (7) is used to describe transport of fine sediment, f represents the rate at which intruding sediments deposit in the interstices of the gravel substrate. The amount of deposition in specific cells is dependent upon how much sediment is already stored within that cell and the process stops when the cell is filled (Alonso et al., 1996).

Oxygen in a redd, is consumed by the organic matter and biological communities within the sediments, by the geochemical redox processes and by the developing embryos in the eggs. Both SIDO and SIDO-UK model the contribution from all three processes but do not account for any oxygen demand from the coarser framework sediments. However, Bateman (in submission) has demonstrated that, on average, only $0.11 \% \pm 0.09 \%$ (9 sites, $\mathrm{n}=32$ ) of SOD in a redd is contributed from particles $>1 \mathrm{~mm}$. SIDO-UK currently works on this assumption. The sediment oxygen consumption (SOC) depends upon the amount and decay rate of organic matter, while the egg oxygen consumption (EOC) depends upon the number of eggs and their rate 
of respiration (Chevalier et al., 1984). SOD is given by the following equation (Theurer \& Theurer, 1986):

$$
\Delta \mathrm{S}_{\mathrm{od}}=\mathrm{a} \Delta \mathrm{M}_{\mathrm{f}}
$$

where $\Delta S_{O D}$ is the change in sediment oxygen demand (mg/l), $a$ is the proportionality constant $\left(\mathrm{mgO}_{2} \mathrm{~g}^{-1}\right.$ sediment $\left.<1 \mathrm{~mm}\right)$, and $\Delta M_{f}$ is the mass of sediment $(<1 \mathrm{~mm})$ added to the redd $(\mathrm{g} / \mathrm{L})$. The proportionality constant $a$ is set in SIDO-UK, but we modified the code to incorporate values determined for the Rede field site. Twelve samples of fine sediment were collected from within the spawning gravels near the redds following storms in March 2011. The method used was based on inserting a stilling well into the gravels and disturbing the framework gravels to a depth of $20 \mathrm{~cm}$ to release the fines, and taking a 5 litre sample (Collins et al., 2005). The samples were stored in a chiller at $4^{\circ} \mathrm{C}$ before returning to the laboratory within 24 hours. The samples were passed through a $1 \mathrm{~mm}$ sieve and incubated at the average temperature recorded from within the redd up to the point of sampling. The proportionality constant was calculated using standard BOD methods (Thomann \& Mueller 1987) and the average of all samples $(n=12)$ used to parameterize the SIDO-UK model. Values of $a$ averaged $39.9+/-15.9 \mathrm{mgO}_{2} \mathrm{~g}^{-1}$ which are higher than those used in the original SIDO model (11.3 $\left.\mathrm{mgO}_{2} \mathrm{~g}^{-1}\right)$ and measured by Greig (2004) from Atlantic salmon redds in four different UK rivers $\left(8.6-23.3 \mathrm{mgO}_{2} \mathrm{~g}^{-1}\right)$.

The rate of oxygen consumption by eggs (EOC) is given by the following equation (Theurer \& Theurer (1986):

$$
E O C=\frac{4 \pi r^{2}\left(D_{\circ}-D_{o \theta}\right)}{\frac{1}{k}+\left(\frac{\delta}{D_{c}}\right)}
$$

where $r$ is the egg radius (cm), $D_{o}$ is the concentration of oxygen of the surrounding water (mg/cc), $D_{o e}$ is the concentration of oxygen within the egg $(\mathrm{mg} / \mathrm{cc}), k$ is the mass transfer coefficient $(\mathrm{cm} / \mathrm{s}), \delta$ is the egg membrane thickness $(\mathrm{cm})$, and $D_{c}$ is the diffusion coefficient of water through the egg membrane $\left(\mathrm{cm}^{2} / \mathrm{s}\right)$.

The sediment oxygen demand remaining at the end of each day is equal to the amount at the beginning of the day plus the amount added during the day less the amount consumed during the day according to:

$$
\mathrm{S}_{\text {od }, \mathrm{i}}=\mathrm{S}_{\text {od, } \mathrm{i}-1}+\Delta \mathrm{S}_{\text {od }}-\mathrm{S}_{\text {or }}
$$

where $S_{o d, i}$ is sediment oxygen demand at the end of the current day, $S_{o d, i-1}$ is sediment oxygen demand at the end of the previous day, $\Delta \mathrm{S}_{\text {od }}$ is additional sediment oxygen demand caused by the current day addition of silt and clay fraction of fine sediment to a given cell within redd (note that the consumption rate is based upon the amount present at the midpoint of the period); and $S_{\text {or }}$ is sediment oxygen consumption for current day. All units are in mg/L (Theurer \& Theurer 1986; Alonso et al., 1996). 
Sediment Oxygen Consumption $\left(\mathrm{S}_{\mathrm{oc}}\right)$ rate follows a classic decay pattern over time, expressed by the following relationship:

$$
\mathrm{S}_{\mathrm{oc}}=\mathrm{S}_{\mathrm{od}}\left(1-\mathrm{e}^{-\mathrm{kt}}\right)
$$

where $\mathrm{k}$ is the deoxygenation constant $\left(\mathrm{day}^{-1}\right)$ and $\mathrm{t}$ is the time (day) (Theurer \& Theurer 1986).

Parameterisation of the SIDO-UK model requires information on the characteristics of the river reach i.e. cross-section morphology (topo-survey), the redd sediment composition of cut and uncut spawning gravels; and inputs of suspended sediment concentration (rating curve plus high and low predictions), water discharge (EA gauging station), and water temperature (Andera optode within the redd). The biological parameters in the model are based on Atlantic salmon and include the number and dimensions of eggs deposited within the redd and their oxygen consumption and development during hatch (Carling et al., 2003). The latter is derived from empirical relationships derived by Crisp (1991). All data are based on daily averaged cross-section values, as required by the model. This requirement results in small flows (modelled flow depths $0.03 \mathrm{~m}$ compared to observed $0.0 \mathrm{~m}$ ) over the period when the redds were exposed; hence the model does not fully simulate conditions of exposure. We accepted this discrepancy on the basis that the model; a) uses measured temperature within the redd and so includes the thermal conditions during periods of exposure, and; b) we set the suspended sediment contribution to zero during periods of redd exposure. In our results, we focus on the model results during periods when the redds were not exposed.

The SIDO-UK model was calibrated for the River Rede field site using the total volume of fine sediment accumulated in the redd over the study period as measured using the infiltration baskets. The calibration parameter used (CBADJ in the model), determines the rate of accumulation of fines into the framework gravels based on the near bed suspended sediment concentration. This parameter was selected following a structured sensitivity analysis that identified it as strongly controlling sediment accumulation and DO within the redd. The masses of fine sediment $(<1 \mathrm{~mm})$ were converted into volumes through the following methodology. Firstly, the pore space within the redd zone was calculated. To do this, the mass of gravel in each basket was converted into a volume, by dividing by its solid density $\left(2,650 \mathrm{kgm}^{-3}\right.$ Carling \& Reader, 1982; Alonso et al., 1996). This volume was then subtracted from the volume of the basket to give the volume of pore space. Secondly, the volume of the deposited fine sediment was calculated. The mass of fines was converted to a volume (bulk density of fine accumulated organic and inorganic sediments $1,730 \mathrm{kgm}^{-3}$ Simetric, 2011), and multiplied by (1-0.42), the latter being the porosity of the fine sediment (Carling \& Reader, 1982; Komura, 1963). The percentage of the redd infilled was then calculated.

\section{Results}

Sediment transport, fine sediment accumulation and intra-gravel flow velocity 
Prior to the experiment, the winter had been the second-coldest since 1995/96 with December 2010 the coldest in over 100 years. Temperatures were generally above average in February 2011, making it the mildest February since 2002. Precipitation was below average during both December 2010 and January 2011 but there were widespread snowfalls in December that persisted into early February. February 2011 was one of the wettest in the last 100 years. As a result, the catchment was already wet before the start of the field experiment.

Figures 2b, and 3a and show the physical conditions experienced at the field site over the incubation period. Battery failure occurred over two dry periods when air temperatures dropped below freezing (18/03/11,10:37 - 29/03/11,14:05 and 14/04/11, 15:05 - 21/04/11, 15:20). Discharge over this period show the rapid response to runoff characteristics of the River Rede, with multiple steeply rising and falling hydrographs. The discharge ranged from $2.13-40.33 \mathrm{~m}^{3} \mathrm{~s}^{-1}$ (flow duration $\mathrm{Q}_{90}-<\mathrm{Q}_{1}$ ). The vertical solid and pecked lines (Fig 3a-c) define the start and end of periods when water levels in the river fell below the level of the redd surface, although field observations at the lowest flows confirmed that dewatering did not occur in the egg zone. Periods of redd exposure were determined from the relationship between redd elevations and water level elevations measured at the upstream EA gauge, and confirmed by field observations. Redd cutting in areas prone to exposure are typically rare, but at this site recent accumulation of gravels over $50 \%$ of channel width may have altered the cross-section and resulting hydraulics of the site. The resulting dataset is novel in monitoring the incubation environment across a broad environmental gradient from bed mobilising flood flows through to redd exposure.

Although the range of suspended sediment load is typical for UK upland rivers (Cooper et al., 2008), the peak values are likely to be over-estimated (Walling, 1977), while the lower values are under-predicted. Modelled peak concentrations reached $1820 \mathrm{mg} / \mathrm{L}$ with an average of $87.2 \mathrm{mg} / \mathrm{L}$ over the incubation period. Sand $(<1 \mathrm{~mm})$ dominated (58.5\%) the particle size distribution of the suspended sediment with silt and clay comprising $39.4 \%$ and $2.1 \%$, respectively. This result is similar to the suspended sediment loads and grainsize reported in the adjacent North Tyne catchment (Sear, 1993). Total load over the study period $\left(164,169\right.$ tonnes; $\left.763 t . \mathrm{km}^{2}\right)$ is 16 times that reported for other similar studies in upland UK streams (Greig et al., 2005a), and 18 times the long term yield measured from sediments in Catcleugh reservoir in the headwaters of the River Rede (Hall 1967).

Bed mobility occurred on six occasions during flood events (Figure 3a-c and Figure $4 a-c)$. The longest period of bed mobility occurred during the first storms after redd cutting and were the result of the movement of the over-loose, freshly cut, material that covered $7.4 \mathrm{~m}^{2}$ of the bed upstream of the impact sensor. The intensity of bed mobility peaked at 30 impacts per 10 minutes during the large flood of March $3^{\text {rd }}$ 2011. The bed had stabilised and the supply of mobile material had become exhausted by the time of the last floods between $30^{\text {th }}$ March and $7^{\text {th }}$ April, because no impacts were recorded.

At the end of the incubation period, an average of $1.34 \pm 0.20 \mathrm{~kg}\left(6.60 \pm 1.30 \mathrm{kgm}^{-2}\right)$ fine sediment $<1 \mathrm{~mm}$ had accumulated in the sediment baskets within the redds of which $94.0 \pm 0.1 \%$ was sand, and $6.0 \pm 1.3 \%$ was silt and clay which indicates a dominant suspended sediment source, but with augmentation of the sand proportion 
by some bedload transport. The average sedimentation rate was $0.45 \pm 0.09 \mathrm{kgm}^{-2}$ week ${ }^{1}\left(0.06 \pm 0.01 \mathrm{kgm}^{-2} \mathrm{day}^{-1}\right)$ which compares closely with data reported over a similar time period from the adjacent catchment of the regulated North Tyne of $0.07-1.54$ $\mathrm{kgm}^{-2}$ week $^{-1}$ (Sear, 1993), but is lower than those data reported in groundwater dominated rivers (Acornley \& Sear, 1999). Organic matter content of the infiltrated sediments $(<0.63 \mu \mathrm{m})$ was $17.7 \pm 0.61 \%$ which closely matched the corresponding value for the suspended solids sample (18.1\%). These values are typical for UK upland rivers and the rivers draining the local geology (Sear, 1993; Sear et al., 2008a).

At the start of the experiment, values of IGV for freshly cut redd gravels were high and similar to those measured at other sites by Greig et al., 2007a (2132 cm.hr-1 \pm 860 $\left.\mathrm{cm} . \mathrm{hr}^{-1}\right)$. Temperature, DO and conductivity readings in the standpipes were identical to the river water $\left(6.9^{\circ} \mathrm{C}, 10.6 \mathrm{mg} / \mathrm{L}, 20 \mu \mathrm{s}\right)$ at the start of the experiment and are indicative of penetration of surface water into the egg zone. At the predicted hatch date, Redds 1 and 2 were exposed, and water depth over Redd 3 was $3 \mathrm{~cm}$. The egg zone was not dewatered in any of the artificial redds. IGV in all the standpipes had dropped to $<1 \mathrm{~cm} . \mathrm{hr}^{-1}$ and DO concentrations were $<0.38 \pm 0.30 \mathrm{mg} / \mathrm{L}$. On withdrawal of the sediment baskets, anoxic reducing conditions were found in redds 1 and 2, as indicated by a sulphurous smell and the presence of black manganese deposits on the stainless steel standpipe. Interstitial water temperature was 1.3 degrees warmer than the river water, and conductivity readings were higher; $63 \mu \mathrm{s}$ in the redd compared to $25 \mu$ s for river water.

Temporal trends in incubation environment over complete incubation period.

Figure $3 \mathrm{a}-\mathrm{c}$ show the variation within the redd environment as defined by thermal and DO regime. Generally, DO and temperature show diurnal fluctuations with daytime maxima and night time minima reflecting solar radiation and net production and consumption of $\mathrm{O}_{2}$ (Malcolm et al., 2009). Increases in the amplitude of the DO and temperature correspond to periods when the river optode was exposed to the air. In comparison, the corresponding temperature values within the redd are dampened, but start to show increasing amplitude as water levels fall lower. Within the redd, DO concentrations reduce to values close to zero $(0.053 \mathrm{mg} / \mathrm{L})$ during periods of exposure, with the onset occurring as water levels fall after the initial flood event (Figure 3b). As water levels rise with increasing runoff, thermal regime in the redd mimics that in the river water though typically slightly warmer. In contrast, although DO concentrations rise to match that of the river water, values continue to fluctuate. During the final period of exposure, DO concentrations exhibit a prolonged phase of ultra-low concentrations, reaching their lowest values of $0.052 \mathrm{mg} / \mathrm{L}$.

The response time of the DO and thermal regime within the redd during exposure and inundation vary. As the redd is exposed, thermal regime responds 48 and 13 hours before exposure whilst DO responds 56 and 2.5 hours before exposure. In contrast, response to inundation is more rapid; with thermal regime reaching the same values as surface water some 2 hours and 1 hour after inundation, and DO responding in 3 hours and 10 hours. We assume that this response relates to the warming of progressively shallowing water as flows recede, in contrast to rapid inundation by cooler, high DO water during flood events.

Temporal trends in incubation environment during periods of redd submergence 
Figures 4a-c reports the results for periods when the redds were submerged. Thermal regime within the redd was on average $0.47^{\circ} \mathrm{C}$ warmer. During the rising limb of the flood events of 24/02/11, 03/04/11 and 07/04/11, redd water became (maximum $0.60^{\circ} \mathrm{C}$ average $0.41^{\circ} \mathrm{C}$ ) warmer relative to river water. Overall, there was some evidence of dampening of the thermal regime within the redd relative to the river but there were no major changes during upwelling or downwelling episodes. Thermal regime in the redd largely tracked river thermal regime though with less variability (Malcolm et al., 2010).

DO in the surface water was fully saturated with low amplitude frequency variations reflecting diurnal and broader trends in air temperature. In contrast, DO within the egg zone of the redd was highly variable and largely independent of thermal regime (Figure 4a-c). The characteristics of the DO regime within the redd during periods of inundation include: 1) DO decline and recovery that were independent of the discharge regime (e.g. 15/03/11, 02/04/11, 04/04/11): 2) DO declines that occured on the rising limb of flood events (e.g. 23/02/11): 3) DO decline and recovery that occured on the falling limb of flood events (e.g. 13-14/03/11); and 4) highly variable rates of DO decline and recovery.

Changes in discharge were associated with changes in DO, but in no consistent pattern. Broadly, there appeared to be more response to discharge earlier in the incubation period (before 02/04/11) with limited response to later events, where DO remained close to zero (Figure 4c). Similarly, early in the incubation period, the DO minima were higher $(>0.6 \mathrm{mg} / \mathrm{l})$ than later in the period when they consistently fell below $0.5 \mathrm{mg} / \mathrm{l}$, and finally below $0.1 \mathrm{mg} / \mathrm{l}$ for extended periods.

Rates of decline and recovery in DO varied, with slower rates of decline associated with the falling limb of floods $\left(0.504-1.699 \mathrm{mgl}^{-1} \mathrm{hour}^{-1}\right)$ when surface water penetrated into the egg zone. Abrupt rates of decline (3.38-9.01 $\mathrm{mgl}^{-1} \mathrm{hour}^{-1}$ ) in DO, which occurred during both the rising limb of floods (e.g. 20/02/11; 23/02/11; 31/03/11) and during periods when discharge was falling slowly (e.g. 15/03/11; 04/04/11), are indicative of upwelling groundwater due to catchment wetting (Malcolm et al., 2009; Soulsby et al., 2009) or possibly oxygen stripping due to the infiltration of organic matter derived from a range of sources during the flood event (Greig et al., 2007b).

Figures 4a-c, reveal episodic phases of bed mobility that did not last more than 10 minutes at a time, but occured over periods of up to 4 hours during a single flood event. Bed mobility occured on either the rising or falling limbs of flood events, and in the case of the large flood on 13/03/11 on both rising and falling limbs. This latter event also witnessed the most intense bed mobility (up to 30 impacts/10 minutes). However, the values of bedload impacts were very low in comparison with those recorded for a steep bedrock channel (up to 1400 impacts/10minutes) by Richardson et al., (2004). Low impact counts correlated with the lack of scour recorded at the sedimentation baskets and suggest that mobility of the bed surface was relatively limited during the period of incubation. This observation may explain the partial response of DO to bed mobility that Sear et al., (2008) have shown to correspond to increases in DO independent of discharge. In the first event (24/02/11 Figure 4a), bed mobility occured on the falling limb of the flood, and was initially characterised by declining DO, followed by rising DO and an increase in frequency of impacts (as 
shown by the closer proximity of the grey bars). The following four bed mobility events $(11 / 03 / 11,12-13 / 03 / 11,14 / 03 / 11,31 / 03 / 11)$ were all characterised by a decline in DO during or following the mobility event. The final event $(05 / 04 / 11)$ showed a minor increase in DO following the bed mobility event.

Figure 5a presents the results of the hydraulic gradient measurements that failed after the first six days and second flood event. Nevertheless, the data do include two flood events that capture episodes of upwelling (positive gradient (head)) that occured on the falling limb of the storm hydrographs. Hydraulic gradient was initially negative (downwelling) following redd cutting and increased as discharge rose. Prior to the peak discharge, hydraulic gradient began to slowly decrease (upwelling starts) before a rapid increase occured 1 hour after flood peak until 5 hours after the first flood peak, head became positive indicating upwelling. A rapid decrease in hydraulic gradient occurred later in the recession after which head remained negative (downwelling) through the second flood. Strength of downwelling decreaseed on the rising limb of the second flood, becoming positive (upwelling) 14 hours after the peak discharge on the recession flows.

Dissolved oxygen levels recorded at the same elevation as the hydraulic gradient data, showed some correspondence with head data. DO decreased within the redd start as discharge rose on the first event, but rapidly decreased as hydraulic gradient levels increased (progressively reducing downflow). Low DO $(<2 \mathrm{mg} / \mathrm{l})$ occurred during the period of upwelling in the first event, but rose sharply during the latter phase of positive head. DO declined again as flows rose, and hydraulic gradient became increasingly negative (downflow). Towards and through the peak discharge, hydraulic gradient showed maximum downwelling and DO values rapidly rose, peaking 4 hours after maximum discharge when hydraulic gradient started to increase (reduced strength of downwelling). DO decreaseed rapidly again as downwelling flow strength declined, and reached a minimum $(0.02 \mathrm{mg} / \mathrm{l})$ as hydraulic gradient became positive (upwelling). Figure $5 \mathrm{~b}$ summarises the variability of DO with hydraulic gradient, showing lower DO during periods of upwelling. Complex responses between the timing of hydraulic gradient discharge and DO result in apparent declines in average DO as strength of downwelling or upwelling increased.

\section{SIDO-UK model results}

Over the period between insertion and retrieval of the sediment baskets, the calibrated SIDO-UK model simulated a fine sediment accumulation in the redd containing the optode of $7.5 \%$ of void space filled for the predicted sediment loads. This result compares with field observations of $8.3 \%$ (percentage error $\pm 9.6 \%$ ). The calibrated model therefore underestimated the amount of infilling compared with the observations. Simulations for the low and high suspended sediment loads based on this calibration, resulted in predicted accumulations of $0 \%$ and $12.8 \%$ of the void volume filled respectively. The lower sediment loads for this calibration were underestimating fine sediment accumulation, whilst the highest were over-predicting by $54 \%$. The field measured values were incorporated within the range of predicted accumulation. In Figure 6a, fine sediment was predicted to accumulate rapidly within the redd during the flood event of the 13/03/11, with a smaller increase during the later flood event of 31/04/11 despite available void space. The higher sediment load simulation predicted earlier and larger accumulation but preserved the step-like nature of the accumulation process. This 'stepping' has been observed in the adjacent River 
North Tyne by Sear (1993), in which individual higher magnitude flood events resulted in an order of magnitude increase in sediment accumulation compared to smaller flood events. The step like nature of the accumulation (Figure 6a) is in accordance with observations from continuous recording fine sediment traps (Fletcher \& McLean 1995).

Figure $6 \mathrm{~b}$ presents the simulated vs. observed daily average DO regime within the redd. Early in the incubation period, the modelled DO was within the range of observed data but failed to predict the highest and lowest DO concentrations observed within the redd. Divergence between the modelled and observed DO increased during the period of redd exposure, when the model failed to account for the processes responsible for the DO depletion. During the flood event of 13/03/11, the observed and modelled DO converged, though overall the model continued to over-predict the observed DO. During flooding (13/03/11, and 04/04/11), DO declined following the increase in fine sediment, and continued to fall to a minimum at recovery of $8.3 \mathrm{mg} / \mathrm{l}$ (a total drop of $2.6 \mathrm{mg} / \mathrm{l}$ over the whole incubation period) as sediment accumulation and the temperature of the stream increased (Figure 6b). The effect of thermal regime only (i.e. no sediment used in the model input files) ploted above the DO curves, and followed the same basic trend as models including sediment. Modelled DO was slightly higher for the low sediment simulation and lower for the high sediment simulation, as expected. Complex interaction between timing of sediment accumulation and the decline in modelled DO due to SOD, resulted in periods where the higher sediment simulation produced a higher modelled DO in the redd compared with that for the predicted sediment load. Towards the end of the incubation phase divergence between modelled DO and observed DO during flooding increased relative to the earlier events, and continued to predict much higher DO in the redd than was observed.

\section{Discussion}

\section{Bed mobility and DO changes}

According to the hypothesis outlined by Milhouse (1982), limited mobilisation of the stream bed over the egg pocket flushes fine sediments blocking the interstitial pores. This process results in enhanced penetration of surface water into the stream bed, and a corresponding equivalence in the temperature and DO with the redd and in the river water (Sear et al., 2008b). The field data from this site showed some evidence for a bed mobility affect on DO within the redd during floods (Figure $4 \mathrm{~b}-\mathrm{c}$ ), but equally there were periods when the bed was mobile and DO declines (Figure 4a). As such, we consider the role of bed mobility at this site as limited compared with the influence of other factors. The main reason for the lack of a bed mobility effect is most probably due to the limited transport of gravel at this site as recorded by the impact sensor, and as evidenced by the lack of net scour at the artificial redds.

\section{Dissolved Oxygen regime: Groundwater upwelling vs sediment accumulation}

The SIDO and the SIDO-UK models have been shown to reproduce DO regimes in redds over a range of river types (Sear, 2010; Alonso et al., 1996). However, in this case, the model was unable to predict DO regime over much of the incubation period despite reasonable calibration with field measurements of fine sediment accumulation. Accumulated sediment $(<1 \mathrm{~mm})$ at this site was largely composed of sand, which is represented in the model. In the SIDO-UK model, sand sized sediment does not 
reduce hydraulic conductivity as much as silt and clay (Alonso et al., 1996). Hence blocking by sand has reduced impact and inter-gravel flow velocities were maintained. Similarly, since DO reduction due to SOD is a function of fine (silt and clay) sediment mass (which as predicted and observed was small) the consumption of DO was also minor. Therefore, it is our hypothesis that the differences between modelled and observed DO was not due to a failure of the model to simulate the sediment and thermal processes of DO consumption, but rather a failure of the model to reproduce the effects of additional processes operating at this site. From this assumption we discuss the relative contribution of fine sediment processes (blocking and SOD), thermal regime and other unaccounted for processes on DO regime within the redd.

Figure 6c shows the variation in percentage contribution to the DO deficit (relative to river DO) made by different processes. At the start of the incubation period, the contribution from sediment was, of course, zero, with thermal regime dominating (55.6\%) and other processes accounting for $44.4 \%$ of the difference. At hatch, sediment accounted for $2.3 \%$, thermal $16.8 \%$ and other factors $80.9 \%$. The contribution from sediment accumulation rose during flood events attaining a maximum effect of 3.1\% during the large flood on 13/04/11. SOD affects towards the end of the incubation period increased the contribution from sediment accumulation to $2.9 \%$. Thermal processes started off dominant, but declined rapidly to $<20 \%$ following the first floods. Cooling during the large flood of the 13/04/11 caused a short-lived increase in thermal process contribution, before declining to $<15 \%$ over the final period to hatch. In contrast, the contribution from non-thermal and sediment processes dominated the DO reduction (relative to stream water). The initial change in dominance from thermal processes occured during periods of upwelling, and reached a maximum when redds were exposed. Thus, at this site we demonstrate that sediment had a relatively minor effect on the DO within the egg zone. We hypothesize that the observed decline in DO was a function of other factors which we attribute on the basis of the (limited) data available on hydraulic gradient, to be upwelling low DO groundwater during periods of redd inundation together with other unaccounted respiration or chemical oxidation processes during periods of high temperature and redd exposure (Larsen et al., 2000). The presence of reducing conditions and manganese precipitation in the egg zone of two of the three redds suggest conditions of low redox potential existed (Larsen et al., 2000). Fuller and Harvey (2000) reported the sequestration of manganese from groundwater within the hyporheic zone of a river due to the downward flux of oxygen from stream water, which stimulated microbial oxidation and precipitation of manganese within shallow sediments. However, without data on VHG or water chemistry our observations during these exposure periods must remain speculative. Clearly, models such as SIDO-UK are currently unable to account for these processes.

DO regime at the study site over the incubation period reflected a range of processes which were operating over different timescales to produce the complex record observed. Early on in the incubation period, DO responded to discharge, but post 02/04/11, subsequent events did not result in such variability, instead DO remained low throughout the last two floods. Soulsby et al. (2009) have observed similar seasonal responses, and suggested that they result from macro-scale processes associated with wetting of the catchment and persistent (high) levels of groundwater. At the event-scale, strong down-welling during peak flows forced DO-rich stream 
water into the egg zone, which was seen by recovery of DO levels and in the head data recorded for the first two events (Figure 5a). In addition, following theory developed by Packman \& Salehin (2003) we hypothesize that sedimentation and rearrangement of the framework particles reduced permeability of the surface gravels and, hence, the effectiveness of the penetration of surface water into the egg zone; thereafter recovery of DO became limited in later flood events. However, when the bed is mobilised, fine sediment can be flushed and river water can penetrate down to the egg zone. Evidence for this action was seen during some bed mobilising floods when DO concentrations rose, but as discussed above, the process of gravel transport was limited at this field site particularly in the later, smaller flood events (Figure 4ac).

Of particular concern to fisheries managers, are the periods of low DO, that occur rapidly, and quasi-independently of discharge. We consider, these periods to represent conditions when the rainfall over the catchment has locally elevated groundwater levels within the floodplain (Malcolm et al., 2009). We hypothesize that this shallow groundwater passes through organic rich sediments which are locally associated with palaeochannels (Hildon, 2005), in which reducing conditions strip oxygen from the water (Lerner, 2009). During periods of low discharge whilst the water-table in the floodplain was high, upwelling groundwater was likely to dominate and we observed DO levels drop significantly (Malcolm et al., 2010). During periods of redd exposure, it is possible that groundwater was dominant, or, stagnant surface water was left within the redd gravels (Curry et al., 1994; Malcolm et al., 2012). The very low values of IGF possibly support the latter hypothesis, but additional chemical analysis of the water would be necessary to deduce its provenance. Thermal regime although showing evidence for warmer water and less temporal variability within the redd compared with the river water, showed limited response to changes in hydraulic gradient (upwelling/downwelling). As Malcolm et al. (2010) demonstrated, significant changes in thermal regime are most marked at deeper locations within the bed than we were able to monitor, and that differences in thermal regime can be quite consistent despite changes in hydraulic gradient at some sites.

\section{Implications for predicting egg survival}

The experimental redds were located on a riffle/run that was immediately downstream of a bank erosion sediment source at a location used by sheep and cattle as an access point to the river. Field observations showed that during high flows, sediment from the site is mobilised as a high concentration suspended sediment plume that passed over the redd sites. To predict the possible survival to hatch of Atlantic salmon eggs based on fine sediment accumulation only, we used an empirical model developed by Kemp et al., (2011). The logistic regression model, is based on a range of published studies of Atlantic salmon egg survival derived from UK rivers using the same field sampling methods. The model predicts egg survival to hatch based solely on the proportion of fine sediment $<1 \mathrm{~mm}$ accumulating in the egg zone. The predicted percentage survival to hatch in the three artificial redds, based on sediment accumulation only, ranged from 12.2 - 26.4\% (Figure 7a). These levels are not uncommon in UK salmon spawning gravels, but would be classified as poormoderate habitat quality according to the method of Greig et al. (2007b). However, these levels of survival do not account for the dissolved oxygen or intergravel flow velocity, which at this site was shown to be most probably a function of factors other than sediment accumulation. 
An alternative approach to predicting the quality of the spawning habitat within the redd was proposed by Greig et al., (2007a;2007b). Using the theory of mass transfer (Daykin, 1965; Chevalier \& Carson, 1985; Carling, 1985) a deterministic model of incubation habitat quality is based on two parameters: DO concentration and IGV in the egg zone. Threshold values for survival based on Atlantic salmon eggs are calculated for combinations of DO and IGV (Daykin, 1965; Wicketts, 1975; Carling, 1985; Greig, 2004). The resulting threshold curves represent the combination of DO and IGV necessary to support the oxygen demand of incubating embryos. Verification of these thresholds has come from redd scale field data (Greig, 2004; Grieg et al., 2007b) Figure $7 \mathrm{~b}$ shows all the available data for salmon spawning sites measured at the point of cutting, during the incubation period and at hatch. Individual points represent direct field measurements from a range of salmon redds reported by Grieg et al. (2007b) and Burke (2011). The data presented by Malcolm et al (2011) are also shown for comparison although they derived IGV data using a different technique. Malcolm et al., (2011) data range across those observed in the field.

Immediately after cutting, salmonid spawning gravels provide high quality habitat able to support development of the embryos (sites plotting above the upper threshold). The present study site also plotted above the upper threshold line, indicating an initially high quality spawning habitat. At hatch, the study site was positioned within the zone where survival is expected to be poor $<5 \%$ (Greig et al., 2007b). In contrast, the modelled conditions within the redd based on sediment and thermal process alone, plotted within the region of good quality spawning habitat in which survival is expected to be high (>75\% Greig et al., 2007b).

The application of two different approaches both point to the current site being of poor to moderate quality in terms of survival to hatch. However, the empirical model based on the proportion of fine $(<1 \mathrm{~mm})$ sediment predicted higher survival than the deterministic model based on mass transfer theory. Modelled values of DO and IGF based on the effects of sediment accumulation and thermal regime were predicted to result in good survival, further demonstrating the inability of the SIDO-UK model to represent all the processes controlling DO regime at the site which would result in over-prediction of spawning habitat quality.

Recent papers (Franssen et al., 2012; Malcolm et al 2011; Ciuhandu et al., 2008; Greig et al., 2007b) provide contrasting evidence for the effectiveness of IGV as a predictor of survival. Mass transfer theory, and its derivatives used within the SIDOUK model, provides the theoretical framework for the role of IGV in supporting the supply of DO required to maintain the oxygen gradient across the egg chorion necessary to support embryo development. As IGV declines, increased DO is required to maintain the supply rate to the boundary layer surrounding the egg, which in turn is needed to support diffusion and advection of oxygen across the chorion (Ciuhandu et al., 2008). Field data collected using the same reproducible and calibrated techniques for measuring IGV in the egg zone (Greig et al., 2005c), and measured in a range of contrasting field conditions in differing rivers, continue to support the improved prediction of survival based on combined IGV and DO measurements (Bateman in submission; Burke, 2011; Greig et al., 2007b; Carling 1985). Furthermore, laboratory studies provide additional evidence for the effect of IGV on survival (Franssen et al., 2012; Ciuhandu et al., 2008). Poor correlations between IGV and survival reported by 
Malcolm et al. (2011) were associated with different techniques for determining IGV and may explain the differences observed. Upwelling groundwater in the absence of significant fine sediment accumulation (Malcolm et al., 2009) understandably results in poor correlations between IGV and survival because the primary control on DO is independent of local hydraulic gradients. However, in situations where fine sediment is the primary control on the quality of the incubation environment, IGV is an important factor controlling incubation success (Greig et al., 2007b). This situation is also likely to be the case where the biochemical oxygen demand of organic materials is high, since residence time strongly influences oxidation processes (Findlay, 1995). We conclude on the basis of our field observations made at the present study site, that like Malcolm et al. (2011), the probable presence of upwelling low DO groundwater exerted a primary control on DO in the redd independently of IGV. However, during periods of low flows and redd exposure, an additional compounding factor was the creation of a stagnant body of water in the egg zone. The resulting conditions during exposure created levels of DO supply $\left(<0.0042 \mathrm{mghr}^{-1}\right)$ that Fig $7 \mathrm{~b}$ identifies with poor survival $(<5 \%)$. Like Franssen et al. (2012) we conclude that the main abiotic factors controlling survival to hatch are DO regime and IGV, but the significance of these varies depending on the processes controlling $\mathrm{DO}$ at a given site.

\section{Implications for habitat management}

As fisheries and catchment managers seek to define more informed targets for fine sediments and conservation limits for salmon production (Collins et al., 2011), increasing field evidence points towards the need for better methods for quantifying the controls on spawning habitat quality. The results of this and similar studies highlight the complexity of the spawning environment, and demonstrate the need for tools to help identify sites at risk not only from enhanced fine sediment loads, but also from upwelling, low DO groundwater, increasing thermal stress, and the presence of materials with high SOD. The challenge remains balancing the high costs and relative site specificity of detailed monitoring against the decline in salmon observed at regional and national scales. A common approach is to develop risk-based tools to screen catchments for factors that could potentially impact spawning habitat quality. Such approaches vary from deterministic (Havis et al., 1993; Reaney, 2011), statistical (Anlauf et al., 2011) to empirical and conceptual models (Lerner, 2009; Lázár, 2010). The results of this and other field based studies point to the need to move away from single risk factor assessments based on an assumption of the main contributory factor (often fine sediment stress), towards multiple risk-based assessments that can identify sites at risk from different, or a range of, risk factors. Where existing or modelled data exist (e,g, Lázár, 2010) then the SIDO-UK model provides a tool to assess the multiple risks of fine sediment, SOD and thermal regime on redd scale spawning habitat quality. However, as we demonstrate, SIDO-UK is currently unsuited to sites with complex groundwater regimes and these support salmonid fisheries across the UK.

Verification of such broad scale risk assessments inevitably demands field based measurements. The simplest approach involves the planting of egg boxes and their removal at hatch and emergence to provide the evidence required to identify if a site is performing poorly, although this is not without uncertainty (Reiser, 1998). At this stage, managers may need to consider more detailed sampling programmes to identify causality. For the latter, measurement of DO is by far the simplest of the techniques available to fisheries managers, providing high resolution direct and immediate data. 
However, as this and other field studies demonstrate, the sampling of DO (or other abiotic factors such as fines content, permeability, water chemistry and IGV) is time critical (Malcolm et al., 2006; Greig et al., 2005a; Groves \& Chandler, 2005). Furthermore, the measurements need to be made in gravels that have been disturbed by redd cutting action rather than by direct assessment gravels in situ regardless of the presence of cutting (Groves \& Chandler, 2005). As this study has demonstrated, measurement of DO alone may not provide sufficient evidence to confirm the causal factor(s). Increasingly, spatial networks of standpipe or intragravel samplers nested in siltation baskets within artificial redds have been used to monitor DO, IGV, hydrochemistry and fine sediment accumulation (Malcolm et al., 2004; Heywood \& Walling, 2007; Greig et al., 2007b). Whilst some factors (e.g. fine sediment accumulation) may be monitored at low sample frequency, the challenge with others (e.g. DO, IGV, hydrochemistry) is that higher resolution sampling is required to capture short-lived changes associated with groundwater or other as yet unaccounted for processes (Malcolm et al., 2010). Similarly, improvements in the ability to measure in-situ DO within the egg zone of spawning gravels has resulted in a more precise definition of the frequency and duration of exposure to low DO experienced by incubating embryo. What remains poorly understood is the impact of low DO epochs on the mortality and subsequent lifestage vitality.

\section{Conclusions}

A combination of field measurement and numerical modelling of the incubation environment within an Atlantic salmon spawning gravel has permitted, for the first time, the relative impacts of fine sediment, thermal regime and other factors (notably upwelling groundwater) on DO concentrations to be quantified. Previous studies (e.g. Malcolm et al., 2010; Hanrahan et al., 2005; Groves \& Chandler, 2005) have inferred the contributions from sedimentary and groundwater processes. The results, though constrained by data and model limitations, demonstrate the importance of factors other than fine sediment and thermal regime on the DO regime within a salmon redd. We hypothesize that the most likely cause of the decreased DO is upwelling low DO groundwater, with possible stagnant water and chemical processes occurring during periods when the redd is exposed. Our field observations show that connectivity between surface water and the egg zone is good during flood events when strongly down welling flows dominate and the thermal regime matches river water. However, even during flood events, DO concentrations exhibit rapid fluctuations that are matched by evidence of upwelling. We, like other investigators, interpret this as evidence of short-term incursions of groundwater into the egg zone. These periods of low DO last for between 0.5 - 250 minutes, creating epochs of potential lethality that can impact development, fitness and mortality of the embryos and alevins (Hicks, 2000). This study also demonstrated that, at this site, the role of bed mobility was minor compared with upwelling groundwater and fine sediment accumulation in the redd. However, there was some evidence for DO recovery following bed mobilising events and this is identified as an additional factor influencing the local incubation environment. Further investigation of the role of bed mobility is needed to inform management of regulated flow regimes over and above empirical correlations between fine sediment mass and embryo survival (Wu \& Chou, 2004). The study highlights the limitations of the SIDO and SIDO-UK models for representing spawning sites with strong non-sediment controls on DO. Finally, the results demonstrate the 
complexity of spawning habitats, and highlight the need for fisheries managers to move towards multi-factor risk assessment of spawning habitat quality.

\section{Acknowledgements}

The authors gratefully acknowledge the funding provided by the Department for Environment, Food and Rural Affairs (DEFRA) under project WQ0128 (Extending the evidence base on the ecological impacts of fine sediment and developing a framework for targeting mitigation of agricultural sediment losses). We also thank all those who helped with the project including Paul Atkinson for field monitoring support (Tyne Rivers Trust), Richard Bond (Kielder hatchery) and the landowner $\mathrm{Mr}$ Ian Davison for permission to access the site. For help with the experimental set up we would like to thank Adele Hulin (ADAS) and Peter Morgan. Jenny Stanford and Peter Morgan processed the sediment samples. The review comments of Iain Malcolm and an anonymous referee are thanked for greatly improving the final paper.

\section{References}

Acornley, R.M. 1999. Water temperatures within spawning beds in two chalk streams and implications for salmonid egg development, Hydrological Processes 13: 3, 439 446.

Acornley, R.M. Sear, D.A. 1999. Sediment transport and the siltation of salmonid spawning gravels in a groundwater dominated river. Hydrological Processes 11: 14, 447 - 458.

Allen, R.A., Gehrels, J., Noakes, D.L.G., Swainson, R. 1994. Effects of river flow fluctuations on groundwater discharge through brook trout, Salvelinus fontinalis, spawning and incubation habitats, Hydrobiologia, 227:121-134.

Alonso, C.V., Theurer, F.D., Zachman, D.W. 1996. Sediment Intrusion and dissolved oxygen transport model - SIDO. Technical Report No. 5, USDA-ARS National Sedimentation laboratory, Oxford, Mississippi; 232p.

Anlauf, K. J., Gaeuman, W., Jones, K. K. 2011. Detection of Regional Trends in Salmonid Habitat in Coastal Streams, Oregon, Transactions of the American Fisheries Society, 140: 1, 52-66.

Brookes, A. 1988. Channelised Rivers. John Wiley \& Sons, Chichester, UK; 320pp.

Brown, C.B. (1950). “Sediment transportation,” In: Engineering hydraulics, Rouse, H., (ed.), John Wiley and Sons, Inc., New York, 135-154.

Burke, N.S. 2011. Physical controls on salmon spawning habitat quality and embryo fitness: an integrated analysis. Unpublished PhD thesis, Geography and Environment, University of Southampton, UK, 351p.

Carling, P.A. \& Reader, N. A. 1982. Structure, composition and bulk properties of upland stream gravels, Earth Surface Processes and Landforms 7: 4, 349-365. 
Carling PA, 1984, Deposition of fine and coarse sand in an open work gravel bed, Canadian Journal of Fisheries and Aquatic Sciences 41; 263-270.

Carling, P.A., Sear, D.A., Greig, S.M., Whitcombe, L.J. 2003. Modelling fine sediment accumulation in salmonid spawning gravels. DEFRA, Final Project Report, London; 21pp.

Chapman D.W. 1988. Critical review of variables used to define effects of fines in redds of large salmonids. Transactions of the American Fisheries Society 117: 1-21.

Chevalier B. E., Carson C., 1985. Modelling the transfer of oxygen between the stream and the stream substrate with application to the survival rates of salmonid embryos. Colorado State University, Department of Agriculture and Chemical Engineering ARS, Report No. 5602 20813-008A; 99p.

Chevalier BE, Carson C, Miller WJ. 1984. Report of engineering and biological literature pertaining to the aquatic environment with special emphasis on dissolved oxygen and sediment effect on salmonid habitat .Colorado State University, Department of Agriculture and Chemical Engineering, ARS Report No. 5602 20813008A.

Ciuhandu, C.S., Wright, P.A., Goldberg, J.I., Stevens, E.D. 2008. Parameters influencing dissolved oxygen in the boundary layer of rainbow trout (Oncorhynchus mykiss) embryos and larvae. Journal of Experimental Biology 210:1435-1445.

Clapham, R.C. 2011. 'Real' hydromorphological quality: linking physical diversity and biodiversity on the River Rede, Northumberland. Unpublished MSc Thesis, School of Applied Sciences, Cranfield University; 78pp.

Collins, A. L., Walling, D. E., \& Leeks, G. J. L., 2005. Storage of fine-grained sediment and associated contaminants within the channels of lowland permeable catchments in the UK. In D.E. Walling \& A. Horowitz (Eds). Proceedings of symposium Sediment Budgets 1 held during the Seventh IAHS Scientific Assembly (pp. 259-268). Foz do Iguacu, Brazil, April 2005, IAHS publication 291.

Collins, A.L., Naden, P.S., Sear, D.A., Jones, J.I., Foster, I.D.L., Monnow, K. 2011. Sediment targets for informing river catchment management:international experience and prospects. Hydrological Processes 25:13, 2112-2129. DOI: 10.1002/hyp.7965.

Cooper, D., Naden, P.S., Old, G., Laizé, C. 2008. Development of guideline sediment targets to support management of sediment inputs into aquatic systems, Natural England Report NERR008. Natural England, Sheffield, UK ISSN 1754-1956; 84pp.

Crisp D. T. 1991. Measurement of stream water temperature and biological applications to salmonid fishes, Grayling and Dace (including ready reckoners). Occasional Publication 29, Freshwater Biological Association; 34pp.

Crisp D. T. and Carling P. A. (1989). Observations on siting, dimensions and structure of salmonid redds. Journal of Fish Biology 34: 119-134. 
Daykin P. 1965. Application of mass transport theory to the problem of respiration of fish eggs. Journal of the fisheries Research Board of Canada 22: 159-170.

DeVries, P. 2008. Bed disturbance processes and physical mechanisms of scour in salmonid spawning habitat, , in Sear, D.A. \& DeVries, P. (ed) Salmonid Spawning habitat in Rivers; Physical controls, biological responses and approaches to remediation. AFS, Bethesda, Maryland, USA; 121-148.

Environment Agency. 2008. The River Tyne Salmon Action Plan Review, APEM Scientific Report EA 410230, Environment Agency, Tyneside House, Newcastleupon-Tyne; 67p.

Findlay, S.1995. Importance of surface-subsurface exchange in stream ecosystems: The hyporheic zone, Limnol. Oceanogr.: 40:1, 159-164

Fletcher, W.K., McLean,W.E. 1995. An Instrument to Monitor Infiltration of Fine Sediment into Stable Gravel Stream Beds, Aqmcultural Engineering: 14, 4, 289-296.

Jan Franssen, J., Blais, C., Lapointe, M., Bérubé,F., Bergeron, N., Magnan, P. 2012. Asphyxiation and entombment mechanisms in fines rich spawning substrates: experimental evidence with brook trout (Salvelinus fontinalis) embryos. Can. J. Fish. Aquat. Sci. 69: 587-599.

Fuller, C. C., J. W. Harvey. 2000. Reactive uptake of trace metals in the hyporheic zone of a mining-contaminated stream, Pinal Creek, Arizona. Environmental Science and Technology 34: 1150-1155.

Greig, S.M. (2004) An assessment of factors influencing the ability of UK spawning gravels to support the respiratory requirements of Atlantic Salmon (Salmo salar) embryos. Unpublished PhD Dissertation, School of Geography, University of Southampton; 322pp

Greig, S.M., Sear, D.A., Carling, P.A. 2005a. Fine sediment accumulation in salmon spawning gravels and the survival of incubating salmon progeny: implications for spawning habitat management. Science of the Total Environment 344: 241-258.

Greig S. M., Sear, D.A., Smallman, D., Carling, P.A. 2005b. Impact of clay particles on cutaneous exchange of oxygen across the chorion of Atlantic salmon eggs. Journal of Fish Biology 66:1681-1691.

Greig S. M., Carling, P.A. and Sear, D.A. 2005c. Refinement and re-calibration of a conductiometric standpipe method of assessing interstitial flow velocities. Hydrobiologia 545: 249-256.

Greig S.M., Sear, P.A. and Carling, P.A., 2007a. A field-based assessment of oxygen supply to incubating Atlantic salmon embryos. Hydrological Processes 21: 3087 3100 . 
Greig S. M., Sear, D.A. \& Carling, P.A. 2007b. Review of factors influencing the availability of dissolved oxygen to incubating salmon embryos. Hydrological Processes 21: 323-324.

Hall, D.G., 1967. The sediment hydraulics of the River Tyne, Unpublished PhD Thesis, Dept. of Civil Engineering, University of Durham; 525pp.

Hannah D.M., Malcolm I.A. and Bradley C. 2009. Seasonal hyporheic temperature dynamics over riffle bedforms, Hydrological Processes 23: 2178-2194.

Havis, R. N., Alonso, C. V., King, J. G. and Thurow, R. F. 1993. A mathematical model of salmonid spawning habitat. Journal of the American Water Resources Association, 29: 435-444.

Hendricks, S.P.and White, D.S. 1991. Physicochemical patterns within a hyporheic zone of a northern Michigan river, with comments on surface water patterns. Canadian Journal of Fisheries and Aquatic Sciences 48: 1645-1654.

Heywood, M.J.T. \& Walling, D.E. 2007. The sedimentation of salmonid spawning gravels in the Hampshire Avon catchment, UK: implications for the dissolved oxygen content of intragravel water and embryo survival, Hydrological Processes, 21: 770 788.

Hicks, M., 2002. Evaluating Criteria for the Protection of Freshwater Aquatic Life in Washington's Surface Water Quality Standards: Dissolved Oxygen, Publication Number 00-10-071, Washington State Department of Ecology, Olympia, WA, USA; 90pp.

Hildon, S. 2006. Holocene flood records from palaeochannel sediments; the River Rede, North Tyne Basin, UK. Department of Geography, University of Newcastle upon Tyne; 277p.

Hobbs, C.H. 1983. A method for determining the dry bulk density of subaqueous sediments, Journal of Sedimentary Research, 53:663-665.

Kemp,P., Sear,D.A., Collins, A.L., Naden, P.S., Jones, J.I., 2011. The impacts of fine sediments on freshwater fish. Hydrological Processes 25: 1800-1821.

Knox, K. 2008. Long term adjustment of morphology and sediment of a regulated river: the Rede, Northumberland. Unpublished BSc Dissertation, Northumbria University; 54pp.

Komura, S., 1963. Sediment transport mechanics: Introduction and properties of sediment, J. Hydraul. Div. 89, 1, 263-266.

Larsen, F., Poulsen, I., Frederiksen, L., Hansen, H.O. Jochimsen, J. 2000. Release of trace elements from sandy aquifer sediments controlled by artifical recharge, in Rosbjerg, R. Ed) Groundwater Research, Balkema, Rotterdam. 191-192. 
Lawler, D.M., Cardenas, B. Old, G.H., Sear, D.A. 2009. Geomorphology and Sediments of the Hyporheic Zone, In: Lerner, D.N. (Ed.) The Hyporheic Handbook. A handbook on the groundwater-surface water interface and hyporheic zone for environment managers. Integrated catchment science programme. Environment Agency Science report: SC050070, Chapter 3; 231-236.

Lázár, A.N., Butterfield, D., Futter, M.N., Rankinen, K., Thouvenot-Korppoo, M., Jarritt, N., Lawrence, D.S.L., Wade, A.J., Whitehead P.G. 2010. An assessment of the fine sediment dynamics in an upland river system: INCA-Sed modifications and implications for fisheries. Science of the Total Environment, 408: 12, 2555-2566.

Lerner, D.N. (Ed.) 2009. The Hyporheic Handbook. A handbook on the groundwatersurface water interface and hyporheic zone for environment managers. Integrated catchment science programme. Environment Agency Science report: SC050070; 264pp.

Malard F. \& Hervant F. 1999. Oxygen supply and the adaptations of animals in groundwater. Freshwater Biology 40:1-30.

Malcolm, I.A., Youngson, A., Soulsby, C. 2003. Survival of salmonid eggs in gravel bed streams: effects of groundwater - surface water interactions. River Research and Applications 19: 303-316.

Malcolm I.A., Soulsby C., Youngson A.F., Hannah D.M., McLaren I.S.,Thorne A., 2004. Hydrological influences on hyporheic water quality: implications for salmon egg survival. Hydrological Processes 18, 1543-1560.

Malcolm, I.A., Soulsby, C., Youngson, A.F. 2006. High frequency logging technologies reveal state dependant hyporheic process dynamics: implications for hydroecological studies. Hydrological Processes 20: 615-622.

Malcolm, I.A., Greig, S.M., Youngson, A.F., Soulsby, C. 2008. Hyporheic influences on salmon embryo survival and performance in Sear, D.A. \& DeVries, P. (Eds.) Salmonid Spawning habitat in Rivers; Physical controls, biological responses and approaches to remediation, AFS, Bethesda, Maryland, USA; 225-248.

Malcolm, I.A., Middlemass, C.A., Soulsby, C., Middlemass, S.J.,Youngson, A.F. 2010. Hyporheic zone processes in a canalised agricultural stream: implications for salmonid embryo survival. Fundam. Appl. Limnol., Arch. Hydrobiol. 176: 4, 319-336

Malcolm, I.A., Youngson, A.F., Soulsby, C., Imholt, C., Fryer, R.J. 2011.Is insterstitial velocity a good predictor of salmonid embryo survival? Transactions of the American Fisheries Society 140: 898-904.

Malcolm, I.A., Gibbins,C.N., Soulsby, C., Tetzlaff, D., Moir, H.J., 2012. The influence of hydrology and hydraulics on salmonids between spawning and emergence: implications for the management of flows in regulated rivers. Fisheries Management and Ecology, DOI: 10.1111/j.1365-2400.2011.00836.x 
Milan, D.J., Heritage, G.L., Large, A.R.G., Charlton, M.E. 2001. Stage dependent variability in tractive force distribution through a riffle-pool sequence. Catena 44: 85109.

Milhous, R.T. 1982.Effect of sediment transport and flow regulation on the ecology of gravel bed rivers, in Hey, R.D., Bathurst, J.C. \& Thorne, C.R. (eds), Gravel bed rivers, J.Wiley, New York, USA: 819-842.

Packman, A.I., Salehin, M. 2003. Relative roles of stream flow and sedimentary conditions in controlling hyporheic exchange. Hydrobiologia, 494: 291-297.

Pattison, I., Sear, D.A., Collins, A.L., Naden, P.S., Jones, I.J., In Review. SIDO-UK: Sediment Intrusion and Dissolved Oxygen in Salmonid redds in UK rivers, Hydrological Processes.

Perkins, C. 2011. Spatial habitat patterning of the Freshwater Pearl Mussel, Margaritifera margaritifera, in the River Rede, North East England. Unpublished MSc Thesis; Durham University.

Petts, G.E., Armitage, P., Castella, E. 1993. Physical habitat changes and macroinvertebrate response to river regulation: the River Rede UK. Regulated Rivers: Research and Management 8: 167-178.

Phillips, J. M., Russell, M. A., Walling, D. E. 2000. Time-integrated sampling of fluvial suspended sediment: a simple methodology for small catchments.

Hydrological Processes 14: 2589-2602.

Reaney S. M., Lane S. N., Heathwaite A. L. and Dugdale L. J.2011: Risk-based modelling of diffuse land use impacts from rural landscapes upon salmonid fry abundance; Ecological Modelling 222: 4,1016-1029.

Richardson, K., Benson, I., Carling, P.A. 2004. An instrument to record sediment movement in bedrock channels, in Bogen, J., Fergus, T. \& Walling, D.E. (Eds) Erosion and sediment transport measurement in rivers: technological and methodological advances, IAHS Pub. 283; 228-235.

Ringer, N.H., Hall, J.D. 1987. Vertical distribution of sediment and organic debris in Coho Salmon (onorchynchus kiutch) redds in three small Oregon streams. Canadian Journal of Fisheries \& Aquatic Sciences 45: 742-746.

Sear, D.A., 1993. Fine sediment infiltration into gravel spawning beds within a regulated river experiencing floods and the ecological implications for salmonids. Regulated Rivers: Research and management 8: 373-390.

Sear, D.A., Carling, P.A., Grieg, S.M. 2005. Fine sediment accumulation in spawning gravels and the effects on interstitial flow, In:Lastra, D.J \& Martinez, P.V., (eds.) Fifth International Symposium on Ecohydraulics: Aquatic Habitats: Analysis \& Restoration, IAHR, Madrid; 808-812. 
Sear, D.A., Frostick, L.B., Rollinson, G., Lisle, T.E. 2008a. The significance and mechanics of fine sediment infiltration and accumulation in gravel spawning beds, in Sear, D.A. \& DeVries, P. (Eds.) Salmonid Spawning habitat in Rivers; Physical controls, biological responses and approaches to remediation. AFS, Bethesda, Maryland, USA, 2008, 149-174.

Sear, D.A., DeVries, P., Greig, S.M. 2008b. Science and the practice of salmonid spawning habitat remediation, in Sear, D.A. \& DeVries, P. (Eds.) Salmonid Spawning habitat in Rivers; Physical controls, biological responses and approaches to remediation. AFS, Bethesda, Maryland, USA; 1-13.

Sear, D.A. 2010. Integrating science and practice for the sustainable management of in-channel salmonid habitat, in Kemp, P. (Ed.) Salmonid Fisheries:Freshwater habitat management.Blackwell Publishing Ltd, Chichester, UK; 81-118.

Simetric (2011) http://www.simetric.co.uk/si_materials.htm accessed November 2012.

Soulsby, C., Malcolm, I.A., Youngson, A.F., Tetzlaff, D., Gibbins, C.N., Hannah, D.M. 2005. Groundwater - surface water interactions in upland Scottish rivers: hydrological, hydrochemical and ecological implications. Scottish Journal of Geology 41: 39-49.

Soulsby, C., Malcolm, I.A., Tetzlaff, D., Youngson, A.F. 2009. Seasonal and Interannual variability in hyporheic water quality revealed by continuous monitoring in a Salmon spawning stream. River Research \& Applications 25: 1304-1319.

Theurer, F.D., Theurer, K.M. 1986. Draft Tucannon River offsite study: dissolved oxygen consumption, USDA unpublished draft report; 28 pp.

Thomann, R. V., and J. A. Mueller. 1987. Principles of surface water quality modeling and control. Harper International Edition, Harper and Row, New York, NY. 488p.

USDA 2011 http://www.ars.usda.gov/Business/docs.htm?docid=5226, accessed December 2011.

Walling, D.E. 1977. Assessing the accuracy of suspended sediment rating curves for a small basin, Water Resources Research 13: 531-538,

Walling, D.E., Moorehead, P.W., 1989. The particle size characteristics of fluvial suspended sediment: an overview. Hydrobiologia 176: 337-350.

Walling, D.E., Collins, A.L., McMellin, G.K. 2003. A reconnaissance survey of the source of interstitial fine sediment recovered from salmonid spawning gravels in England and Wales. Hydrobiologia 497: 91-108.

Wickett W. P. 1975. Mass transfer theory and the culture of fish eggs. In Chemistry and Physics of Aqueous Gas Solutions, Adams W. A. (ed). The Electro Chemical Society; Princeton: 521pp. 
Wu, F. \& Chou, Y. 2004. Trade-offs associated with sediment maintenance flushingflows:A simulation approach for exploring non-inferior options, River Research and Applications 20: 591-604. 


\section{Figures \& Tables}

Table 1: Physical characteristics of the study field site and catchment.

Figure 1: a) Study site location in the catchment of the River Rede, Northumberland, UK; b) spawning site set up (image based on Google Earth, 2011); c) Schematic of the experimental redd set up.

Figure 2: a) Rating curve between stream discharge and suspended sediment concentration during rising and falling limb of hydrograph; b) rating curve estimates of suspended sediment regime suring the incubation period showing predictions based on the upper and lower envelopes in the data. Observed data is shown. The three modelled suspended sediment loads were used to parameterize the SIDO-UK model.

Figure 3: Physical conditions at the field site: a) discharge (solid black line), suspended sediment (solid grey line) and bed load impacts (solid back bars). b) Dissolved oxygen in the river (solid grey line) and redd (solid black line). c) Thermal regime in the river (solid grey line) and in the redd (solid black line). Periods when the redds were exposed are marked by increased amplitude in thermal and DO as the river probes are exposed. Vertical solid and pecked lines denote the start and end of a period of redd exposure.

Figure 4: Physical conditions at the field site during three periods (4a-c) when the redds were inundated. Dissolved oxygen concentration in the redd water initially matches stream water but during flood events and increasingly in periods following floods, DO decreases to almost zero. Thermal regime remains slightly warmer in the redd but similar to stream water throughout periods of inundation. Bed mobility on 24/02/11 (4a) appears to coincide with an increase in DO and cooling, however subsequent episodes of mobility have no detectable effect.

Figure 5: a) Vertical hydraulic gradient changes over the first floods of the incubation periods prior to equipment failure. Upwelling starts on the rising limb of both floods (reduced downwelling), becoming positive (upwelling) on the falling limb of both flood hydrographs. These periods are associated with lower DO; b) average (and standard deviation) in DO for different bins of hydraulic gradient. Upwelling flows (positive) are associated with lower concentration DO although complexity in the relative timing of the response in vertical hydraulic gradient and DO accounts for reduced DO at higher negative and positive bins.

Figure 6: Results from SIDO-UK modelling of the field site. a) suspended sediment and temperature used to parameterise the model and the resulting modelled sediment accumulation within the redd. Fine sediment accumulates rapidly during the large flood event of the 13/03/11.b) Modelled vs observed Dissolved Oxygen showing the minor changes derived from sediment accumulation. Minimum and maximum rating curve envelopes are used to create the upper and lower sediment simulations. Observed DO within the redd is highly variable and larger than the minimum and maximum sediment predictions. c) Variable contributions to the DO budget within the redd based on the difference between observed river and redd DO. Sediment accumulation and Sediment Oxygen Demand contribute the least, followed by thermal regime. Factors other than these dominate the DO regime which we observe to be 
largely the result of upwelling low DO groundwater during periods of redd inundation, and probably Redox reactions during periods of redd exposure.

Figure 7: Predictions of embryo survival based on two approaches a) an empirical (logistic) regression model of the percent survival in response to different levels of fine sediment $(<1 \mathrm{~mm})$ accumulation in the redd after Kemp et al., (2011). b) The relationship between observed Intragravel Flow Velocity (IGV) and observed Dissolved Oxygen concentration in the redd. Threshold curves are calculated from mass transfer theory after Daykin (1965) and Greig et al., (2007b). Note the modelled impact of fine sediment accumulation results in a small reduction in spawning habitat quality compared to the measured affects of redd exposure at the end of the incubation period. Points on the graph refer to measured data from salmon redds in a range of rivers using the same techniques and equipment. The data of Malcolm et al., (2011) although collected using different techniques, plots within the observed field data. 


\begin{tabular}{|lc|}
\hline Catchment Data & \\
\hline National grid reference & NY889926 \\
Altitude & 150 \\
Drainage area $\left(\mathrm{km}^{2}\right)$ & 215 \\
Stream order & $5^{\text {th }}$ \\
Predominate valley form & Floodplain \\
Mean precipitation $(1966-90)(\mathrm{mm})$ & 941 \\
Mean temperature $(1966-90)(\mathrm{mm})$ & 8.41 \\
\hline Annual data & \\
\hline Discharge (mean) $\left(\mathrm{m}^{3} \mathrm{~s}^{-1}\right)$ & 3.78 \\
95\% exceedance $\left(\mathrm{m}^{3} \mathrm{~s}^{-1}\right)$ & 0.384 \\
10\% exceedance $\left(\mathrm{m}^{3} \mathrm{~s}^{-1}\right)$ & 9.07 \\
\hline Field season data & \\
\hline Discharge (range) $\left(\mathrm{m}^{3} \mathrm{~s}^{-1}\right)$ & $1.62-36.0$ \\
Discharge (mean) $\left(\mathrm{m}^{3} \mathrm{~s}^{-1}\right)$ & 3.89 \\
Flow depth (range) $\left(\mathrm{m}^{2}\right)$ & $0.0-2.11$ \\
Flow depth (mean) $\left(\mathrm{m}^{2}\right)$ & 0.392 \\
Channel width (m) & 14.5 \\
Channel slope & 0.0015 \\
\hline Surface bed material & \\
\hline $\mathrm{D}_{50}$ (mm) & 46.0 \\
D95 $(\mathrm{mm})$ & 59.1 \\
\hline Subsurface bed material & \\
\hline $\mathrm{D}_{50}$ (mm) & 26.9 \\
D95 $(\mathrm{mm})$ & 54.3 \\
$\mathrm{D}_{\mathrm{g}}$ (mm) & 16.3 \\
\% sand & 12.37 \\
\% silt/clay & 10.48 \\
\hline
\end{tabular}

Table 1 

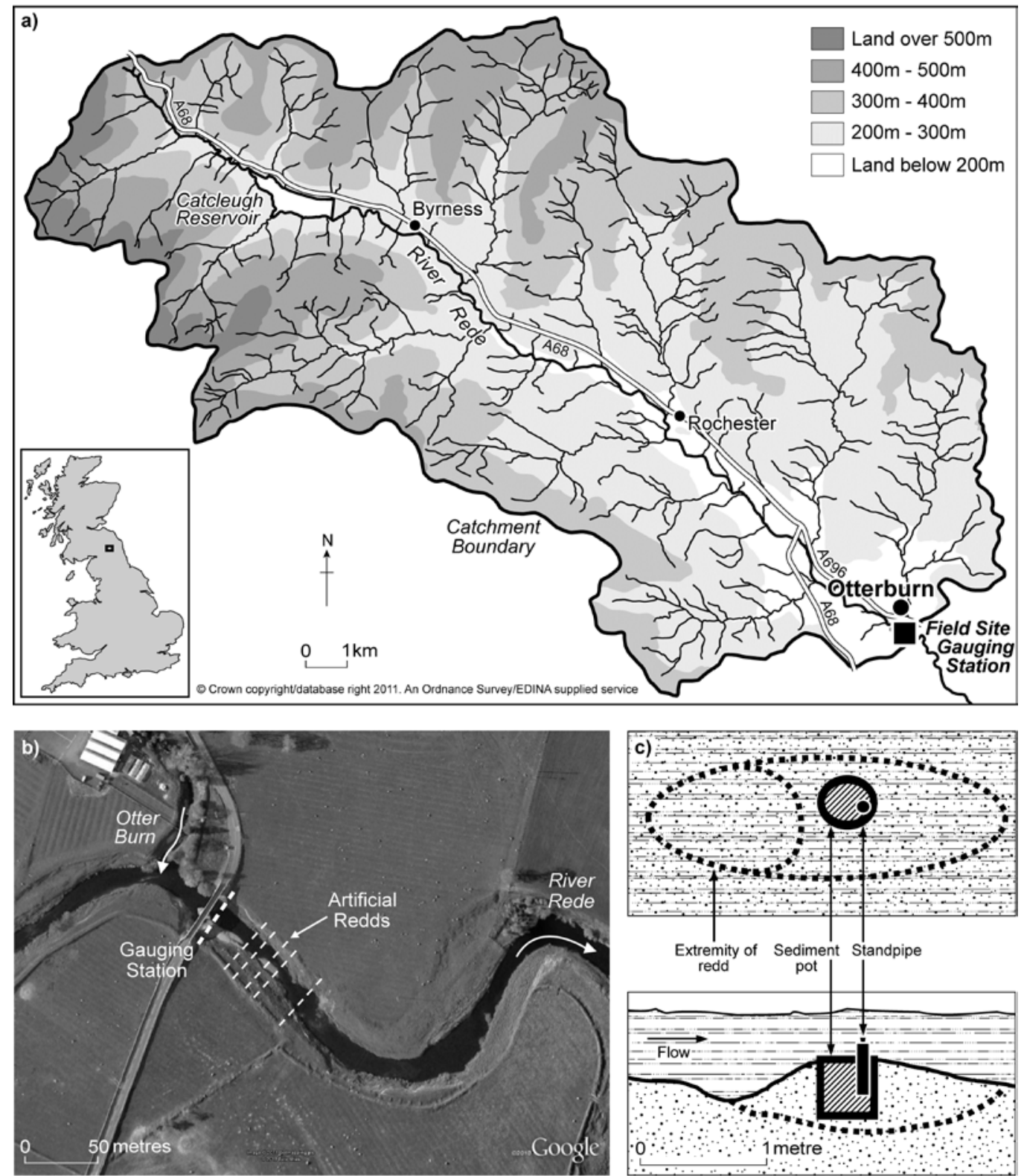

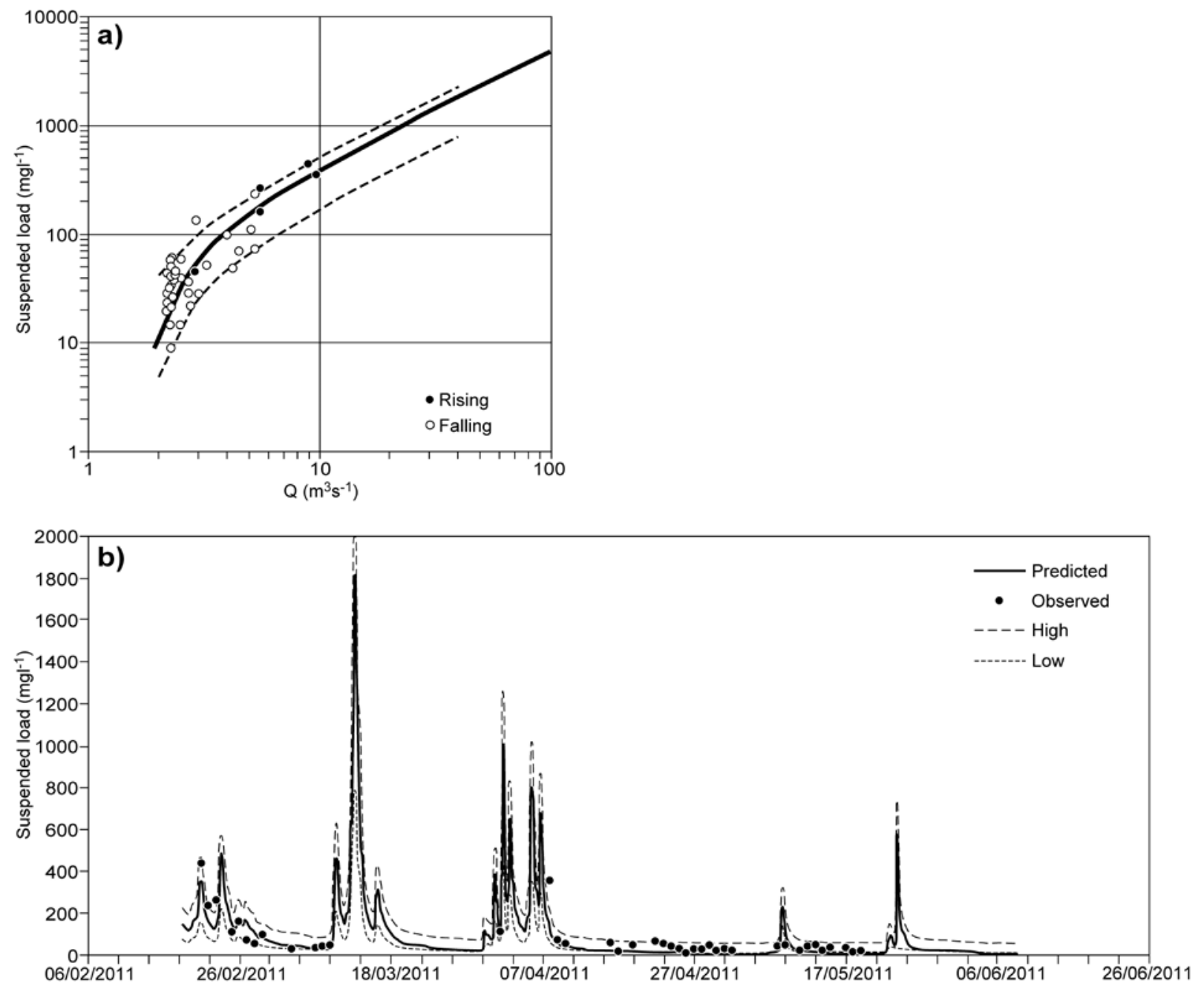

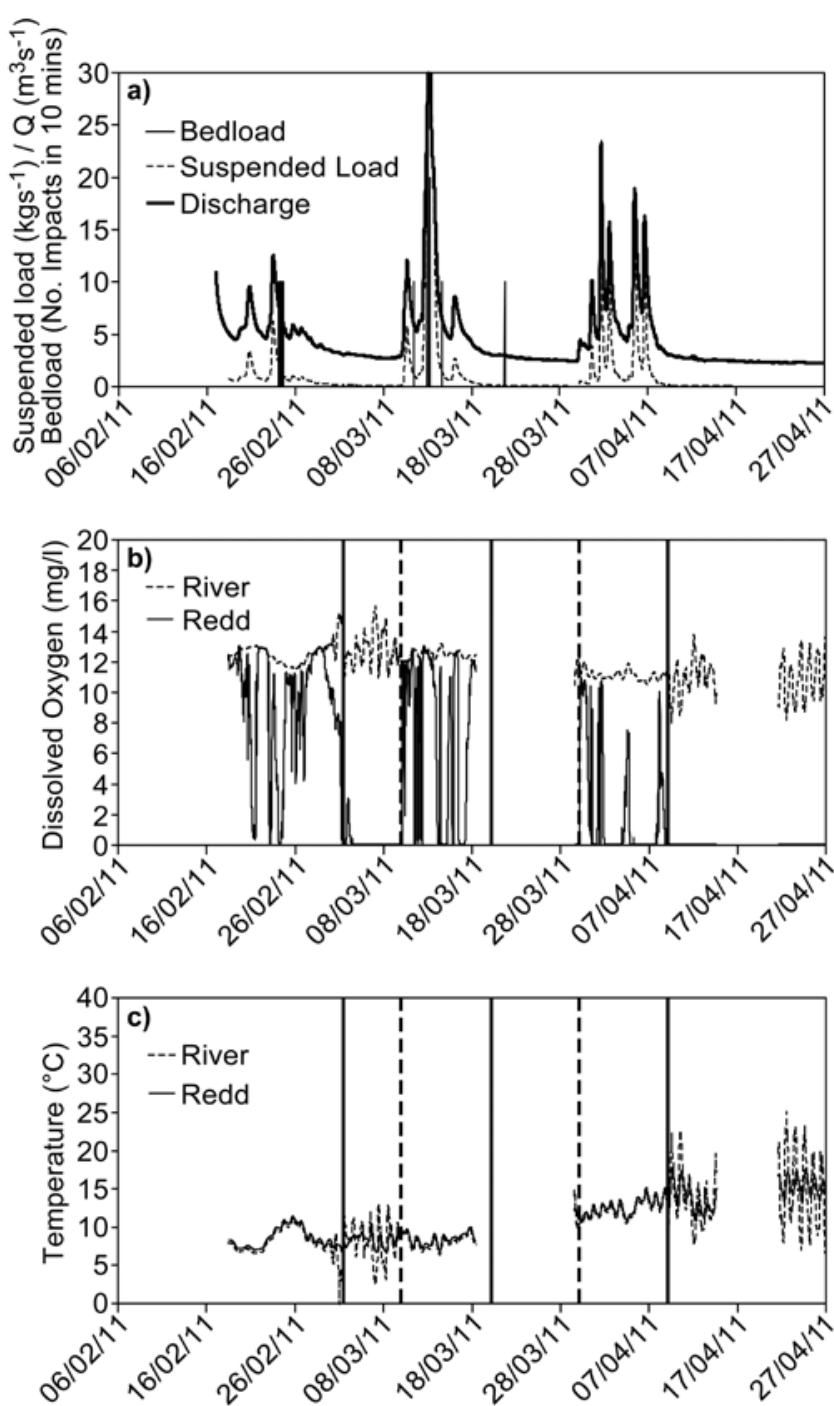


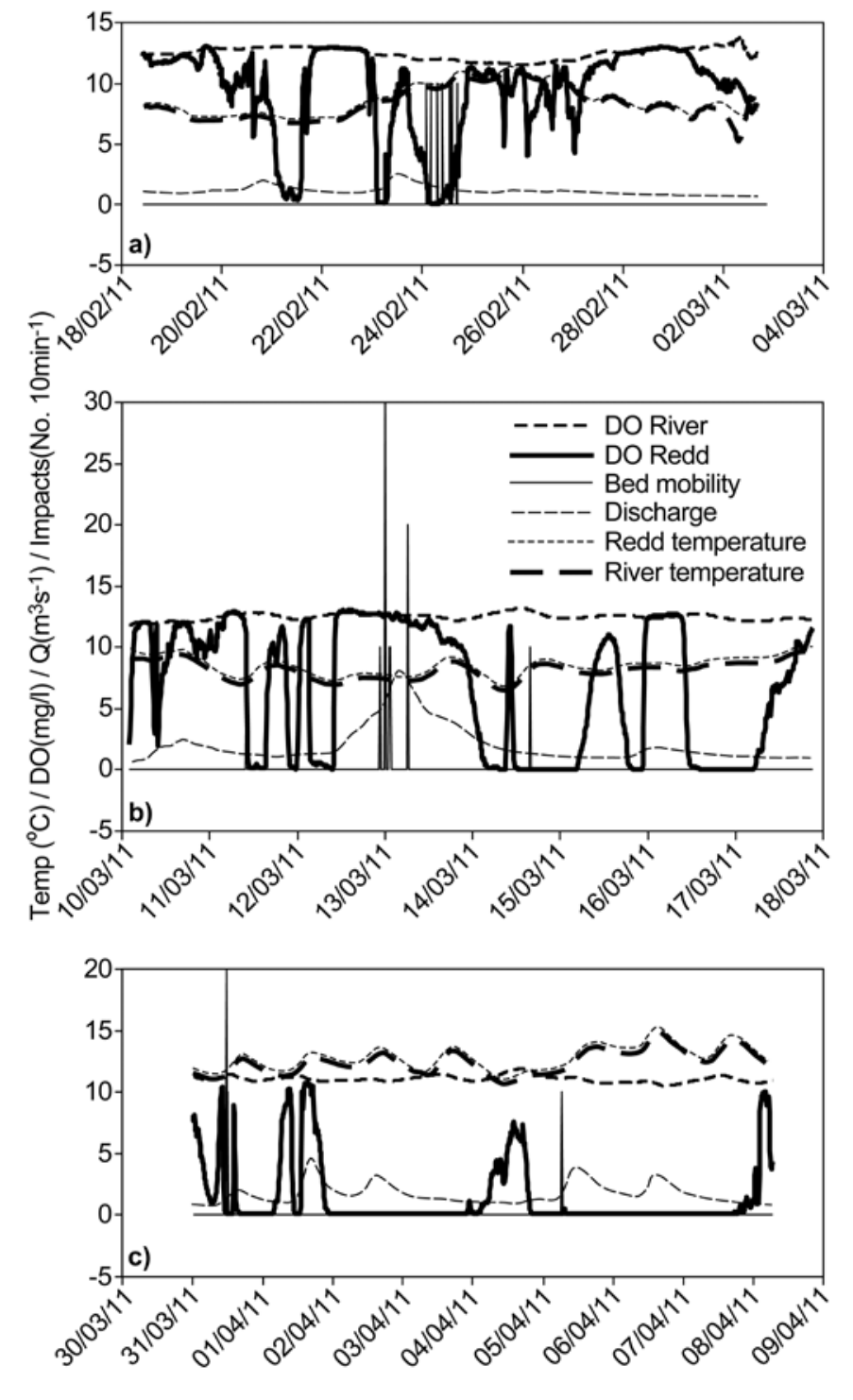



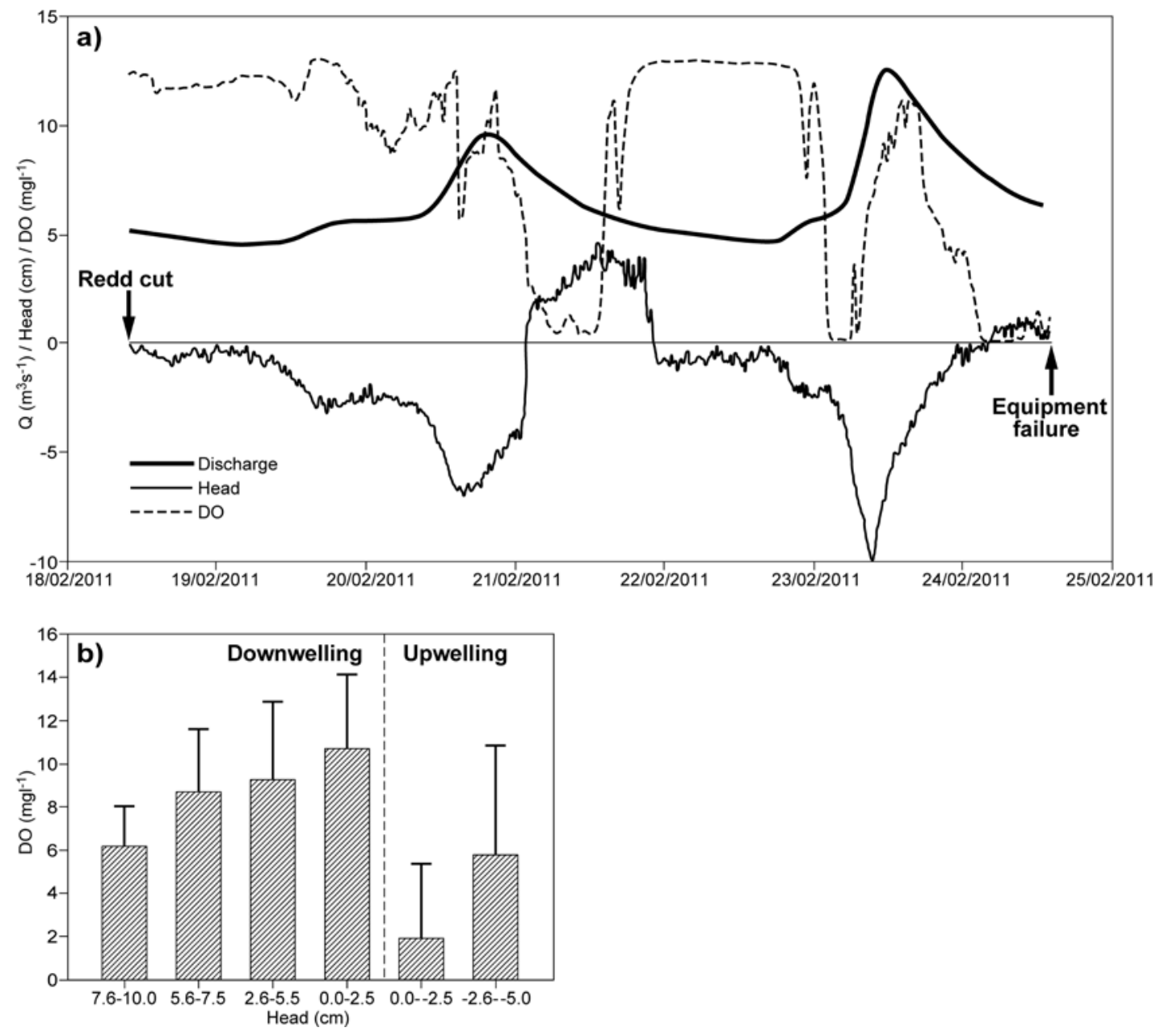

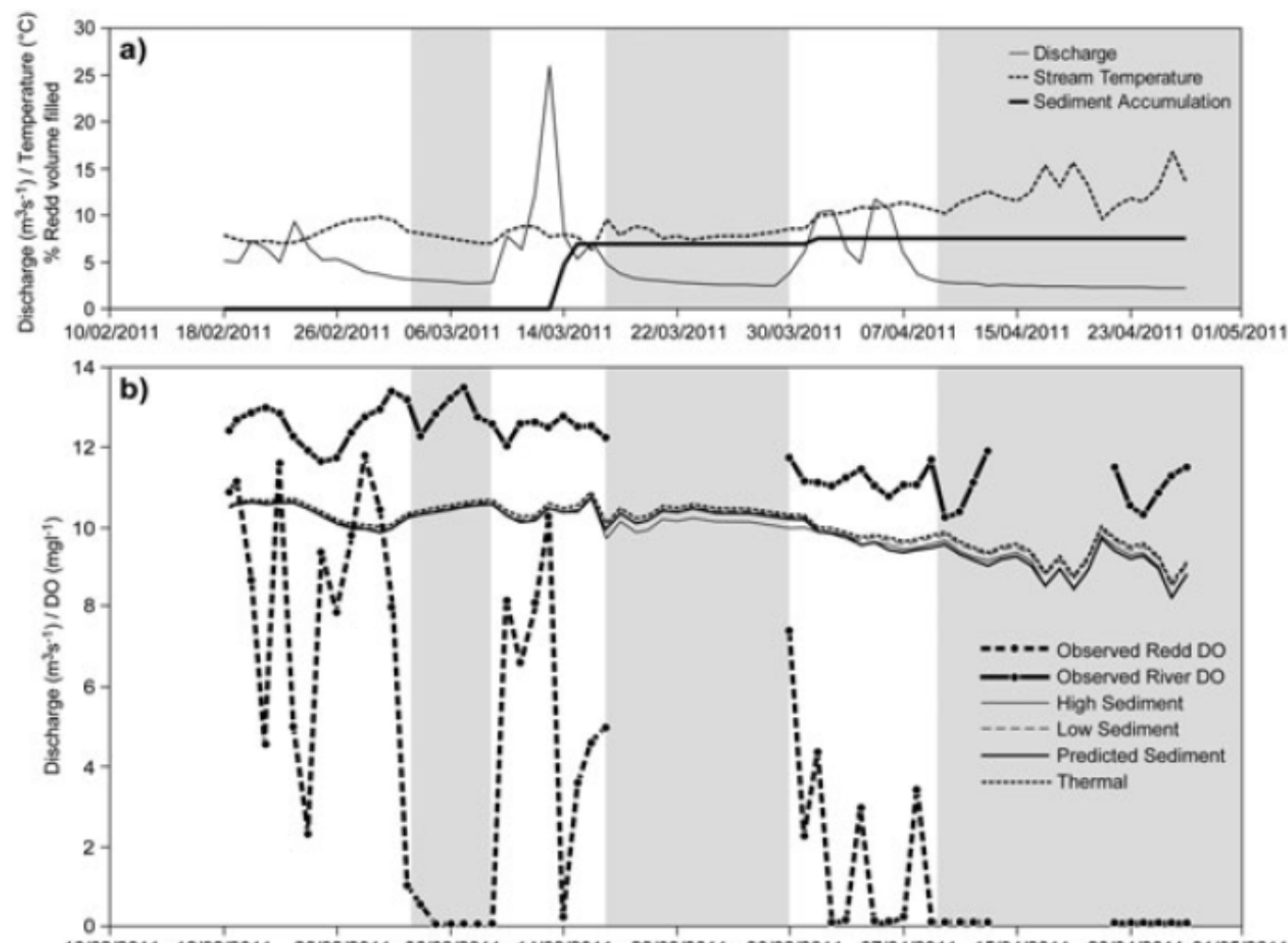

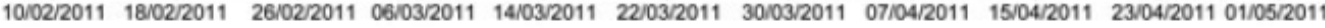

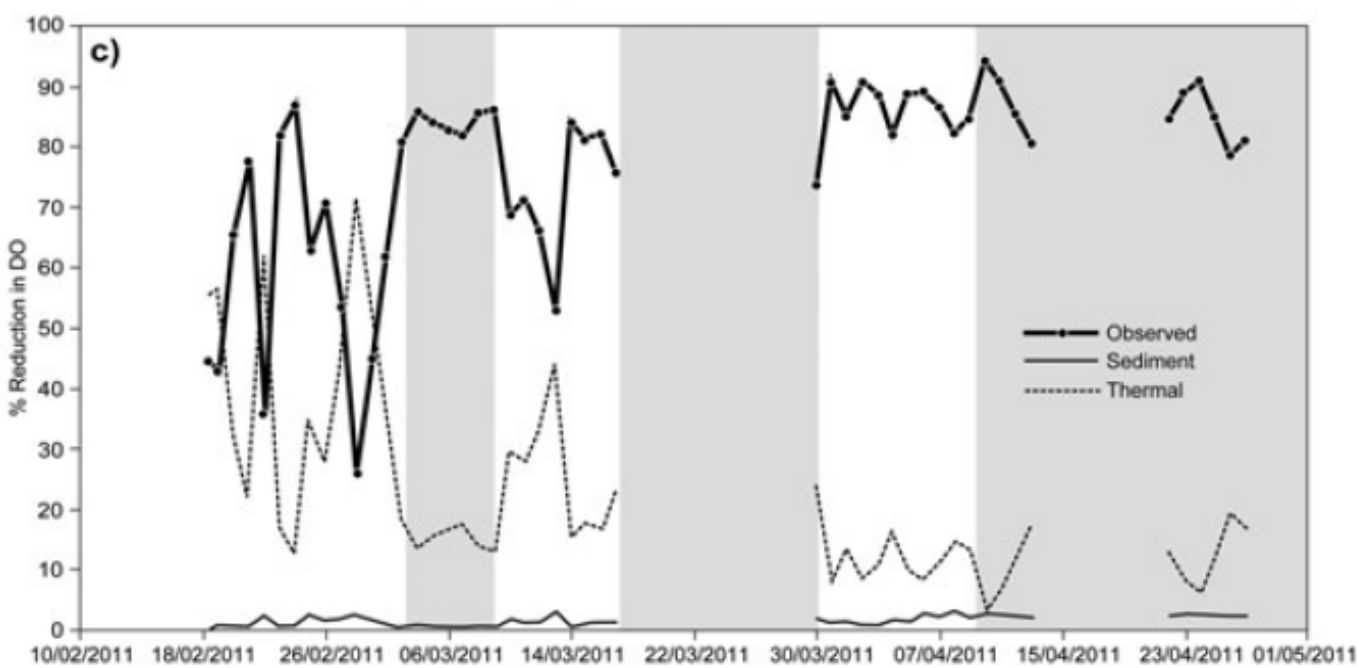



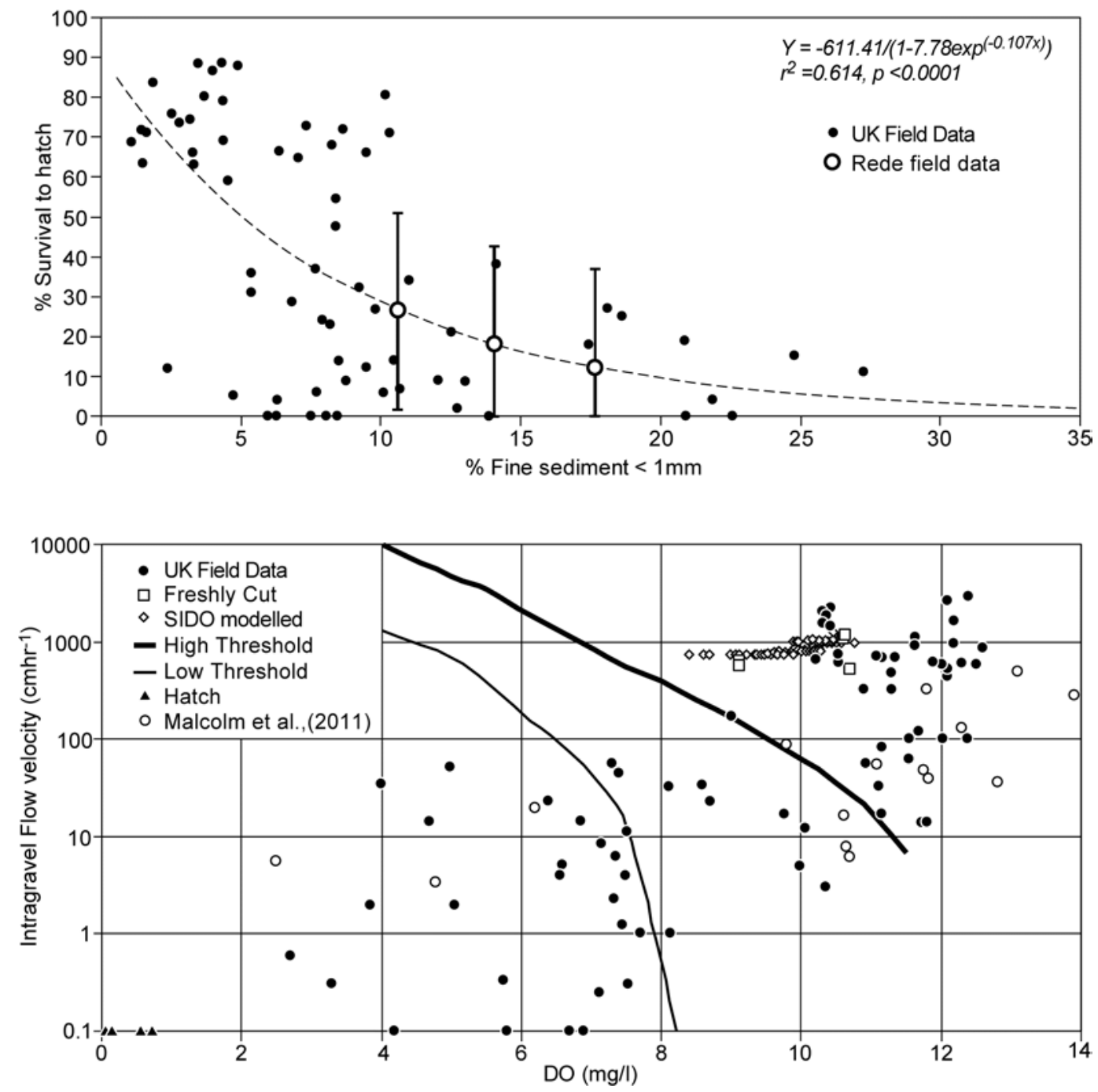